Supporting Information for

\title{
Deoxygenation of Primary Amides to Amines with Pinacolborane
}

\section{Catalyzed by $\mathrm{Ca}\left[\mathrm{N}\left(\mathrm{SiMe}_{3}\right)_{2}\right]_{2}(\mathrm{THF})_{2}$}

Chong Yu, ${ }^{\mathrm{a}}$ Chenjun Guo, ${ }^{\mathrm{a}}$ Linhong Jiang, ${ }^{\mathrm{a}}$ Mingliang Gong, ${ }^{\mathrm{c}}$ and Yunjie Luo ${ }^{*, \mathrm{a}, \mathrm{b}}$

${ }^{a}$ School of Materials Science and Chemical Engineering, Ningbo University, Ningbo

$$
\text { 315211, P. R. China }
$$

${ }^{\mathrm{b}}$ Key Laboratory of Advanced Mass Spectrometry and Molecular Analysis of Zhejiang Province, Ningbo 315211, P. R. China

${ }^{\mathrm{c}}$ The Barstow School Ningbo Campus, Ningbo 315201, P. R. China

*Email: luoyunjie@nbu.edu.cn

\section{Contents}

1. General procedures.

2. General procedure for tertiary amide reduction $\quad$ S5

3. General procedure for secondary amide reduction $\quad$ S6

4. General procedure for primary amide reduction $\quad$ S6

5. Table S1. Optimization of the reaction conditions for the reduction of $\begin{array}{ll}\text { 4-methylbenzamide } & \text { S7 }\end{array}$

6. Reaction of $\mathrm{Ca}\left[\mathrm{N}\left(\mathrm{SiMe}_{3}\right)_{2}\right]_{2}(\mathrm{THF})_{2}$ with $\mathrm{HB}$ pin to understand catalytic active species

S8

7. Reaction of $\mathrm{Ca}\left[\mathrm{N}\left(\mathrm{SiMe}_{3}\right)_{2}\right]_{2}(\mathrm{THF})_{2}$ with $p$-methylbenzamide to understand catalytic active species

8. Reaction of $p$-methylbenzamide with HBpin without catalyst and further workupS13

9. Isolation and characterization of mono-borylated-amide intermediate $p-\mathrm{MePhCONH}(\mathrm{Bpin})$

10. Reaction of $p-\mathrm{MePhCONH}_{2}$ with $\mathrm{HBpin}$ catalyzed by $\mathrm{Ca}\left[\mathrm{N}\left(\mathrm{SiMe}_{3}\right)_{2}\right]_{2}(\mathrm{THF})_{2}$ at 
$120^{\circ} \mathrm{C}$.

11. Reaction of $p$-MePhCONH(Bpin) with HBpin catalyzed by $\begin{array}{lr}\mathrm{Ca}\left[\mathrm{N}\left(\mathrm{SiMe}_{3}\right)_{2}\right]_{2}(\mathrm{THF})_{2} \text { at ambient temperature. } & \mathrm{S} 18\end{array}$

12. Reaction of $p$-MePhCONH(Bpin) with HBpin catalyzed by $\begin{array}{ll}\mathrm{Ca}\left[\mathrm{N}\left(\mathrm{SiMe}_{3}\right)_{2}\right]_{2}(\mathrm{THF})_{2} \text { at elevated temperature }\left(120^{\circ} \mathrm{C}\right) . & \mathrm{S} 20\end{array}$

$\begin{array}{ll}\text { 13. Characterization of amines. } & \text { S22 }\end{array}$

$\begin{array}{ll}\text { 14. Reference } & \text { S40 }\end{array}$

Scheme S1. Reaction of $\mathrm{Ca}\left[\mathrm{N}\left(\mathrm{SiMe}_{3}\right)_{2}\right]_{2}(\mathrm{THF})_{2}$ with $\mathrm{HBpin}$ in $\mathrm{C}_{6} \mathrm{D}_{6} . \quad \mathrm{S} 8$

Scheme S2. Reaction of $\mathrm{Ca}\left[\mathrm{N}\left(\mathrm{SiMe}_{3}\right)_{2}\right]_{2}(\mathrm{THF})_{2}$ with $p$-MePhCONH${ }_{2}$ in $\mathrm{C}_{6} \mathrm{D}_{6} . \mathrm{S} 11$

Scheme S3. Reaction of $p$-methylbenzamide with HBpin in $\mathrm{C}_{6} \mathrm{D}_{6} . \quad \mathrm{S} 13$

Scheme S4. Reaction of $p-\mathrm{MePhCONH}_{2}$ with $\mathrm{HBpin}$ catalyzed by $\mathrm{Ca}\left[\mathrm{N}\left(\mathrm{SiMe}_{3}\right)_{2}\right]_{2}(\mathrm{THF})_{2}$ at $120{ }^{\circ} \mathrm{C} . \quad \mathrm{S} 17$

Scheme S5. Reaction of p-MePhCONH(Bpin) with HBpin catalyzed by $\begin{array}{ll}\mathrm{Ca}[\mathrm{N}(\mathrm{SiMe} 3) 2] 2(\mathrm{THF}) 2 \text { at ambient temperature. } & \mathrm{S} 18\end{array}$

Scheme S6. Reaction of $p$-MePhCONH(Bpin) with HBpin catalyzed by $\mathrm{Ca}\left[\mathrm{N}\left(\mathrm{SiMe}_{3}\right)_{2}\right]_{2}(\mathrm{THF})_{2}$ at $120^{\circ} \mathrm{C}$.

Figure S1. ${ }^{1} \mathrm{H}$ NMR spectrum of $\operatorname{pinBN}\left(\mathrm{SiMe}_{3}\right)_{2}$ generated in situ from the reaction of $\mathrm{Ca}\left[\mathrm{N}\left(\mathrm{SiMe}_{3}\right)_{2}\right]_{2}(\mathrm{THF})_{2}$ with $\mathrm{HBpin}$ in 1:2 molar ratio at ambient temperature in $\mathrm{C}_{6} \mathrm{D}_{6}$.

S8

Figure S2. ${ }^{1} \mathrm{H}$ NMR spectrum of $\operatorname{pinBN}\left(\mathrm{SiMe}_{3}\right)_{2}$ and $\mathrm{HN}\left(\mathrm{SiMe}_{3}\right)_{2}$ generated in situ from the reaction of $\mathrm{Ca}\left[\mathrm{N}\left(\mathrm{SiMe}_{3}\right)_{2}\right]_{2}(\mathrm{THF})_{2}$ with HBpin in 1:2 molar ratio at $50^{\circ} \mathrm{C}$ in $\mathrm{C}_{6} \mathrm{D}_{6}$.

Figure S3. ${ }^{1} \mathrm{H}$ NMR stack $\left(\mathrm{C}_{6} \mathrm{D}_{6}\right)$ showing $\mathrm{HN}\left(\mathrm{SiMe}_{3}\right)_{2}, \mathrm{Ca}\left[\mathrm{N}\left(\mathrm{SiMe}_{3}\right)_{2}\right]_{2}(\mathrm{THF})_{2}$, $\operatorname{pinBN}\left(\mathrm{SiMe}_{3}\right)_{2}$ and $\mathrm{HN}\left(\mathrm{SiMe}_{3}\right)_{2}$ generated in situ from the reaction of $\mathrm{Ca}\left[\mathrm{N}\left(\mathrm{SiMe}_{3}\right)_{2}\right]_{2}(\mathrm{THF})_{2}$ with HBpin in 1:2 molar ratio at ambient temperature and $50{ }^{\circ} \mathrm{C}$ in C6D6. $\quad \mathrm{S} 10$

Figure S4. FT-IR spectroscopy of insoluble [Ca-H] species, like [BpinCaH] $(\mathrm{KBr})$. 
Figure S5. ${ }^{1} \mathrm{H}$ NMR spectrum of the soluble product generated in situ from $\mathrm{Ca}\left[\mathrm{N}\left(\mathrm{SiMe}_{3}\right)_{2}\right]_{2}(\mathrm{THF})_{2}$ and p-methylbenzamide in 1:2 molar ratio in $\mathrm{C}_{6} \mathrm{D}_{6}$.

Figure S6. FT-IR spectroscopy of $\mathrm{Ca}[(\mathrm{CONH}) \mathrm{PhMe}]_{2}(\mathrm{THF})$ species $(\mathrm{KBr}) . \quad \mathrm{S} 12$ Figure S7. ${ }^{1} \mathrm{H}$ NMR spectrum of products formed in situ from the reaction of p-methylbenzamide with $\mathrm{HB}$ pin in $\mathrm{C}_{6} \mathrm{D}_{6}$.

Figure S8. ${ }^{1} \mathrm{H}$ NMR spectrum of $\mathrm{p}-\mathrm{MePhCONH}(\mathrm{Bpin})$ in $\mathrm{CDCl}_{3}$, $*$ residual $\mathrm{O}(\text { Bpin })_{2}$

Figure S9. ${ }^{13} \mathrm{C}$ NMR spectrum of p-MePhCONH(Bpin) in $\mathrm{CDCl}_{3} \quad \mathrm{~S} 166$

Figure S10. ${ }^{11} \mathrm{~B}$ NMR spectrum of p-MePhCONH(Bpin) in $\mathrm{CDCl}_{3} . \quad \mathrm{S} 16$

Figure S11. ${ }^{1} \mathrm{H}$ NMR spectrum of the product from the reaction of p-MePhCONH${ }_{2}$ with $\mathrm{HBpin}$ catalyzed by $\mathrm{Ca}\left[\mathrm{N}\left(\mathrm{SiMe}_{3}\right)_{2}\right]_{2}(\mathrm{THF})_{2}$ at 120 ${ }^{\circ} \mathrm{C}$.

Figure S12. ${ }^{1} \mathrm{H}$ NMR spectrum of the imine from the reaction of p-MePhCONH(Bpin) with HBpin catalyzed by $\mathrm{Ca}\left[\mathrm{N}\left(\mathrm{SiMe}_{3}\right)_{2}\right]_{2}(\mathrm{THF})_{2}$ at ambient temperature.

Figure S13. ${ }^{1} \mathrm{H}$ NMR stack $\left(\mathrm{CDCl}_{3}\right)$ showing the imine from the reaction of p-MePhCONH(Bpin) with HBpin catalyzed by $\mathrm{Ca}\left[\mathrm{N}\left(\mathrm{SiMe}_{3}\right)_{2}\right]_{2}(\mathrm{THF})_{2}$ at ambient temperature and $\mathrm{p}-\mathrm{MePhCONH}(\mathrm{Bpin})$ materials

Figure S14. ${ }^{1} \mathrm{H}$ NMR spectrum of the product generated in situ from the reaction of p-MePhCONH(Bpin) with $\mathrm{HB}$ pin catalyzed by $\mathrm{Ca}\left[\mathrm{N}\left(\mathrm{SiMe}_{3}\right)_{2}\right]_{2}(\mathrm{THF})_{2}$ at $120^{\circ} \mathrm{C}$.

Figure $\mathrm{S} 15 .{ }^{1} \mathrm{H}$ NMR stack $\left(\mathrm{C}_{6} \mathrm{D}_{6}\right)$ showing the product generated from the reaction of $\mathrm{p}-\mathrm{MePhCONH}_{2} / \mathrm{p}-\mathrm{MePhCONH}(\mathrm{Bpin})$ with $\mathrm{HBpin}$ catalyzed by $\mathrm{Ca}\left[\mathrm{N}\left(\mathrm{SiMe}_{3}\right)_{2}\right]_{2}(\mathrm{THF})_{2}$ at $120{ }^{\circ} \mathrm{C}$.

Figure S16. ${ }^{1} \mathrm{H}$ NMR spectrum of 1 in $\mathrm{C}_{6} \mathrm{D}_{6}(400 \mathrm{MHz}, \mathrm{ppm})$.

Figure S17. ${ }^{1} \mathrm{H}$ NMR spectrum of 2 in $\mathrm{C}_{6} \mathrm{D}_{6}$ (400 MHz, ppm).

Figure S18. ${ }^{1} \mathrm{H}$ NMR spectrum of 3 in $\mathrm{C}_{6} \mathrm{D}_{6}(500 \mathrm{MHz}, \mathrm{ppm})$.

Figure S19. ${ }^{1} \mathrm{H}$ NMR spectrum of 4 in $\mathrm{C}_{6} \mathrm{D}_{6}(500 \mathrm{MHz}, \mathrm{ppm})$.

Figure S20. ${ }^{1} \mathrm{H}$ NMR spectrum of 5 in $\mathrm{C}_{6} \mathrm{D}_{6}(400 \mathrm{MHz}, \mathrm{ppm})$. 
Figure S21. ${ }^{1} \mathrm{H}$ NMR spectrum of 6 in $\mathrm{C}_{6} \mathrm{D}_{6}(500 \mathrm{MHz}, \mathrm{ppm})$.

Figure S22. ${ }^{1} \mathrm{H}$ NMR spectrum of 7 in $\mathrm{D}_{2} \mathrm{O}$ (400 MHz, ppm).

Figure S23. ${ }^{1} \mathrm{H}$ NMR spectrum of 8 in $\mathrm{D}_{2} \mathrm{O}$ (400 MHz, ppm).

Figure S24. ${ }^{1} \mathrm{H}$ NMR spectrum of 9 in $\mathrm{D}_{2} \mathrm{O}$ (400 MHz, ppm).

Figure S25. ${ }^{1} \mathrm{H}$ NMR spectrum of 10 in $\mathrm{D}_{2} \mathrm{O}$ (400 MHz, ppm).

Figure S26. ${ }^{1} \mathrm{H}$ NMR spectrum of 11 in $\mathrm{D}_{2} \mathrm{O}$ (400 MHz, ppm).

Figure S27. ${ }^{1} \mathrm{H}$ NMR spectrum of 12 in $\mathrm{D}_{2} \mathrm{O}$ (400 MHz, ppm). S33

Figure S28. ${ }^{1} \mathrm{H}$ NMR spectrum of 13 in $\mathrm{D}_{2} \mathrm{O}$ (400 MHz, ppm). S34

Figure S29. ${ }^{1} \mathrm{H}$ NMR spectrum of 14 in $\mathrm{D}_{2} \mathrm{O}(500 \mathrm{MHz}, \mathrm{ppm})$. S35

Figure S30. ${ }^{1} \mathrm{H}$ NMR spectrum of 15 in $\mathrm{D}_{2} \mathrm{O}$ (400 MHz, ppm). S36

Figure S31. ${ }^{1} \mathrm{H}$ NMR spectrum of 16 in $\mathrm{D}_{2} \mathrm{O}(500 \mathrm{MHz}, \mathrm{ppm})$. S37

Figure S32. ${ }^{1} \mathrm{H}$ NMR spectrum of 17 in $\mathrm{D}_{2} \mathrm{O}(500 \mathrm{MHz}, \mathrm{ppm})$. S38

Figure S33. ${ }^{1} \mathrm{H}$ NMR spectrum of 18 in $\mathrm{D}_{2} \mathrm{O}$ (400 MHz, ppm). 
1. General procedures. All manipulations were performed under pure argon with rigorous exclusion of air and moisture using standard Schlenk techniques and in a purified argon-filled glovebox. High temperature reactions were carried out in an oil bath outside the glovebox. Solvents, toluene, $n$-hexane and THF, were distilled from sodium/benzophenone ketyl, degassed by the freeze-pump-thaw method, and dried over fresh $\mathrm{Na}$ chips in the glovebox. $\mathrm{CaI}_{2}$ was purchased from $3 \mathrm{~A}$ Chemicals (Shanghai, China), and used as received. Pinacolborane (HBpin) was purchased from Sigma Aldrich Co., and distilled under high-vacuum. $\mathrm{Ca}\left[\mathrm{N}\left(\mathrm{SiMe}_{3}\right)_{2}\right]_{2}(\mathrm{THF})_{2},{ }^{1}$ amides were commercially purchased, or were synthesized according to the literature. ${ }^{2}$

Samples of the reaction products for NMR spectroscopic measurements were prepared in the glovebox using J. Young type, PTFE-valved NMR tubes. NMR measurements were performed on a Bruker Ascend 500 spectrometer $(500 \mathrm{MHz}$ for ${ }^{1} \mathrm{H} ; 126 \mathrm{MHz}$ for ${ }^{13} \mathrm{C} ; 160 \mathrm{MHz}$ for ${ }^{11} \mathrm{~B}$ ), or on a Bruker Ascend 400 spectrometer (400 MHz for ${ }^{1} \mathrm{H}$ ) at room temperature. The FT-IR spectra were recorded on a Nicolet 6700 series spectrometer, samples were prepared in a glovebox and mixed with $\mathrm{KBr}$ powder.

\section{General procedure for tertiary amide reduction}

In a NMR tube, tertiary amide $(0.25 \mathrm{mmol})$, pinacolborane (160 mg, $1.25 \mathrm{mmol})$, $\mathrm{Ca}\left[\mathrm{N}\left(\mathrm{SiMe}_{3}\right)_{2}\right]_{2}(\mathrm{THF})_{2}(6.3 \mathrm{mg}, 0.0125 \mathrm{mmol})$, and mesitylene (0.07 mmol, $\left.9.25 \mu \mathrm{L}\right)$, were combined in $\mathrm{C}_{6} \mathrm{D}_{6}(0.8 \mathrm{~mL})$ at room temperature. After $4 \mathrm{~h},{ }^{1} \mathrm{H}$ NMR yield was determined based on the internal standard mesitylene. The product peaks were integrated with respect to the $\mathrm{Ph}-H$ peak of mesitylene which was normalized to 1 . 


\section{General procedure for secondary amide reduction}

In a Schlenk flask, secondary amide (0.25 mmol), pinacolborane (160 mg, 1.25 $\mathrm{mmol}), \mathrm{Ca}\left[\mathrm{N}\left(\mathrm{SiMe}_{3}\right)_{2}\right]_{2}(\mathrm{THF})_{2}(6.3 \mathrm{mg}, 0.0125 \mathrm{mmol})$, and mesitylene $(0.07 \mathrm{mmol}$, $9.25 \mu \mathrm{L})$ were combined in $\mathrm{C}_{6} \mathrm{D}_{6}(0.8 \mathrm{~mL})$. The flask was taken out from the glovebox, and heated in an oil bath at $120{ }^{\circ} \mathrm{C}$. After $24 \mathrm{~h},{ }^{1} \mathrm{H}$ NMR yield was determined based on the internal standard mesitylene. The product peaks were integrated with respect to the $\mathrm{Ph}-H$ peak of mesitylene which was normalized to 1 .

\section{General procedure for primary amide reduction}

In a Schlenk flask, primary amide $(0.25 \mathrm{mmol})$, pinacolborane $(160 \mathrm{mg}, 1.25 \mathrm{mmol})$ and $\mathrm{Ca}\left[\mathrm{N}\left(\mathrm{SiMe}_{3}\right)_{2}\right]_{2}(\mathrm{THF})_{2}(6.3 \mathrm{mg}, 0.0125 \mathrm{mmol})$ were combined in toluene. The flask was taken out from the glovebox, and heated in an oil bath at $120{ }^{\circ} \mathrm{C}$ for $36 \mathrm{~h}$. The reaction mixture was hydrolyzed with $1 \mathrm{M} \mathrm{HCl}$ in ether $(10 \mathrm{~mL})$. The volatiles were removed under reduced pressure, and the residue was washed with ethyl acetate $(3 \times 5 \mathrm{~mL})$ to give a pure desired product as an ammonium salt. The ${ }^{1} \mathrm{H}$ NMR spectra of the isolated ammonium salts were recorded in $\mathrm{D}_{2} \mathrm{O}$. 
5. Table S1. Optimization of the reaction conditions for the reduction of 4-methylbenzamide<smiles>Cc1ccc(CN(Cc2ccc(C)cc2)Cc2ccc(CNC(=O)c3ccc(C)cc3)cc2)cc1</smiles>

\begin{tabular}{|c|c|c|c|c|c|c|}
\hline Entry & $\begin{array}{c}\text { [Cat.]/[amide] } \\
(\%)\end{array}$ & $\begin{array}{l}\text { HBpin } \\
\text { (equiv) }\end{array}$ & Solvent & $\begin{array}{l}\text { Temp. } \\
\left({ }^{\circ} \mathrm{C}\right)\end{array}$ & $\begin{array}{l}\text { Time } \\
\text { (h) }\end{array}$ & $\begin{array}{c}\text { Yield }^{c} \\
(\%)\end{array}$ \\
\hline 1 & 5 & 5 & Tol. & 25 & 24 & 10 \\
\hline 2 & 5 & 5 & Tol. & 60 & 24 & 54 \\
\hline 3 & 5 & 5 & Tol. & 120 & 24 & 90 \\
\hline 4 & 5 & 5 & Tol. & 120 & 12 & 70 \\
\hline 5 & 3 & 5 & Tol. & 120 & 24 & 77 \\
\hline 6 & 1 & 5 & Tol. & 120 & 24 & 58 \\
\hline 7 & 5 & 5 & THF & 60 & 24 & 51 \\
\hline 8 & 5 & 5 & Benzene & 120 & 36 & $97^{b}$ \\
\hline
\end{tabular}




\section{Reaction of $\mathrm{Ca}\left[\mathrm{N}\left(\mathrm{SiMe}_{3}\right)_{2}\right]_{2}(\mathrm{THF})_{2}$ with $\mathrm{HBpin}$ to understand catalytic active} species

In a NMR tube, $\mathrm{Ca}\left[\mathrm{N}\left(\mathrm{SiMe}_{3}\right)_{2}\right]_{2}(\mathrm{THF})_{2}(25 \mathrm{mg}, 0.05 \mathrm{mmol})$, HBpin $(14.7 \mu \mathrm{L}, 0.1$ mmol) and mesitylene $(0.05 \mathrm{mmol}, 7 \mu \mathrm{L})$ were combined in $\mathrm{C}_{6} \mathrm{D}_{6}(0.8 \mathrm{~mL})$ at room temperature. After $0.5 \mathrm{~h}$, the soluble product formed in situ was characterized by ${ }^{1} \mathrm{H}$ NMR spectroscopy. ${ }^{1} \mathrm{H}$ NMR (400 MHz, $\left.\mathrm{C}_{6} \mathrm{D}_{6}, \mathrm{ppm}\right): \delta 3.61\left(\mathrm{~m}, \mathrm{THF}-\alpha-\mathrm{CH}_{2}\right), 1.40$ (m, THF- $\beta-\mathrm{CH}_{2}$ ), 1.03 (s, 12H, Bpin), 0.36 (s, 18H, SiMe $)$. Then, the NMR tube was heated at $50^{\circ} \mathrm{C}$ overnight. ${ }^{1} \mathrm{H}$ NMR $\left(400 \mathrm{MHz}, \mathrm{C}_{6} \mathrm{D}_{6}, \mathrm{ppm}\right): \delta 3.58\left(\mathrm{~m}, \mathrm{THF}-\alpha-\mathrm{CH}_{2}\right)$, 1.43 (m, THF- $\beta-\mathrm{CH}_{2}$ ), 1.03 (s, 12H, Bpin), 0.36 (s, 18H, SiMe $)_{3}, 0.09$ (s, 18H, $\left.\mathrm{HN}(\mathrm{SiMe})_{2}\right)$ (Figure S1-S2).

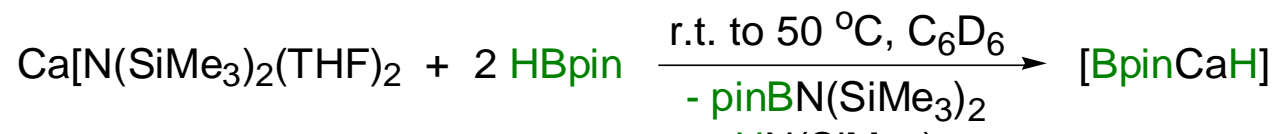

$$
\begin{aligned}
& \text { - } \mathrm{HN}\left(\mathrm{SiMe}_{3}\right)_{2}
\end{aligned}
$$

Scheme S1. Reaction of $\mathrm{Ca}\left[\mathrm{N}\left(\mathrm{SiMe}_{3}\right)_{2}\right]_{2}(\mathrm{THF})_{2}$ with $\mathrm{HBpin}$ in $\mathrm{C}_{6} \mathrm{D}_{6}$.

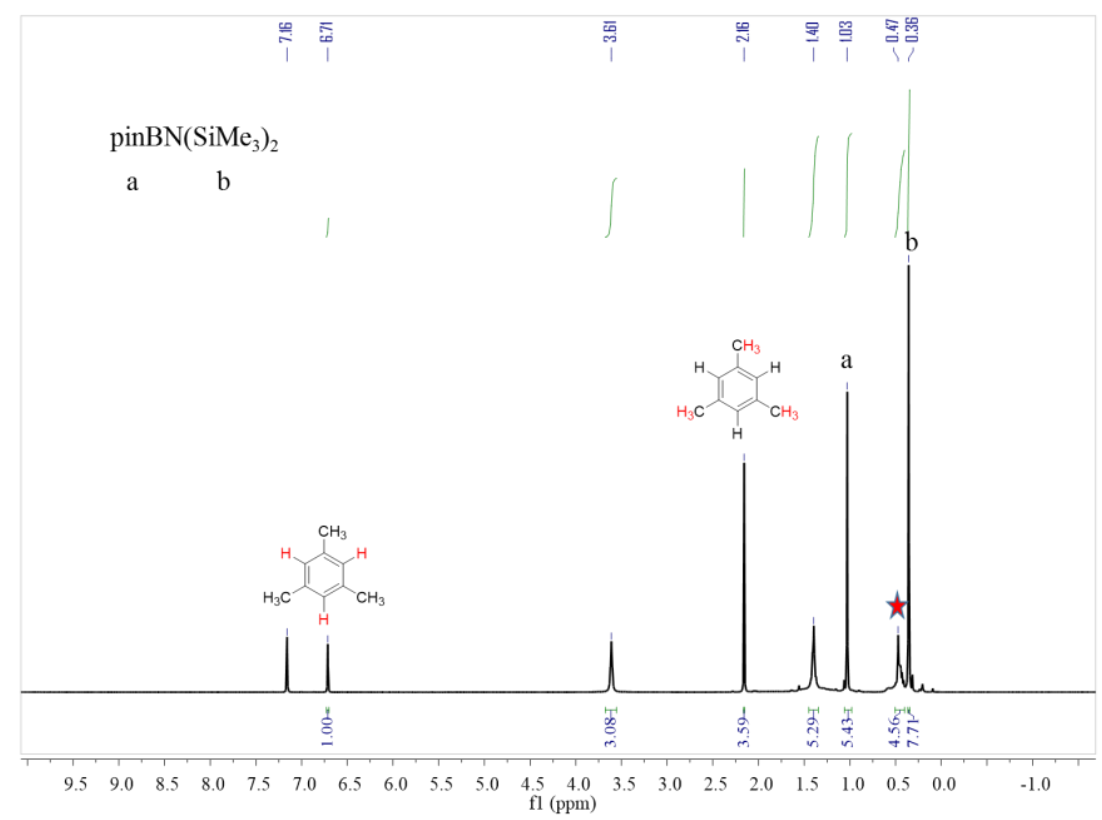

Figure S1. ${ }^{1} \mathrm{H}$ NMR spectrum of $\operatorname{pinBN}\left(\mathrm{SiMe}_{3}\right)_{2}$ generated in situ from the reaction of $\mathrm{Ca}\left[\mathrm{N}\left(\mathrm{SiMe}_{3}\right)_{2}\right]_{2}(\mathrm{THF})_{2}$ with HBpin in 1:2 molar ratio at ambient temperature in $\mathrm{C}_{6} \mathrm{D}_{6}$. 


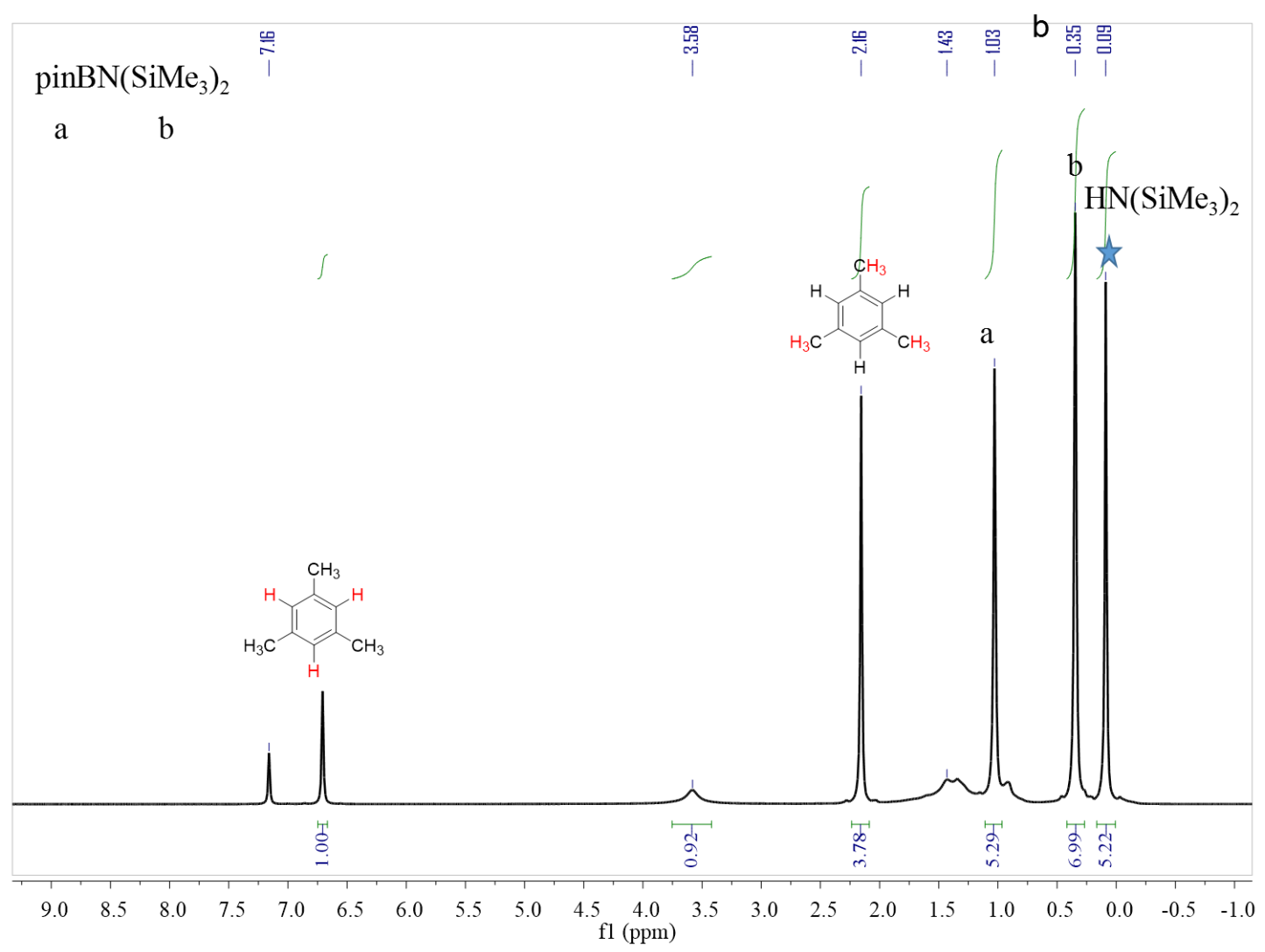

Figure S2. ${ }^{1} \mathrm{H}$ NMR spectrum of $\operatorname{pinBN}\left(\mathrm{SiMe}_{3}\right)_{2}$ and $\mathrm{HN}\left(\mathrm{SiMe}_{3}\right)_{2}$ generated in situ from the reaction of $\mathrm{Ca}\left[\mathrm{N}\left(\mathrm{SiMe}_{3}\right)_{2}\right]_{2}(\mathrm{THF})_{2}$ with $\mathrm{HBpin}$ in $1: 2$ molar ratio at $50^{\circ} \mathrm{C}$ in $\mathrm{C}_{6} \mathrm{D}_{6}$. 


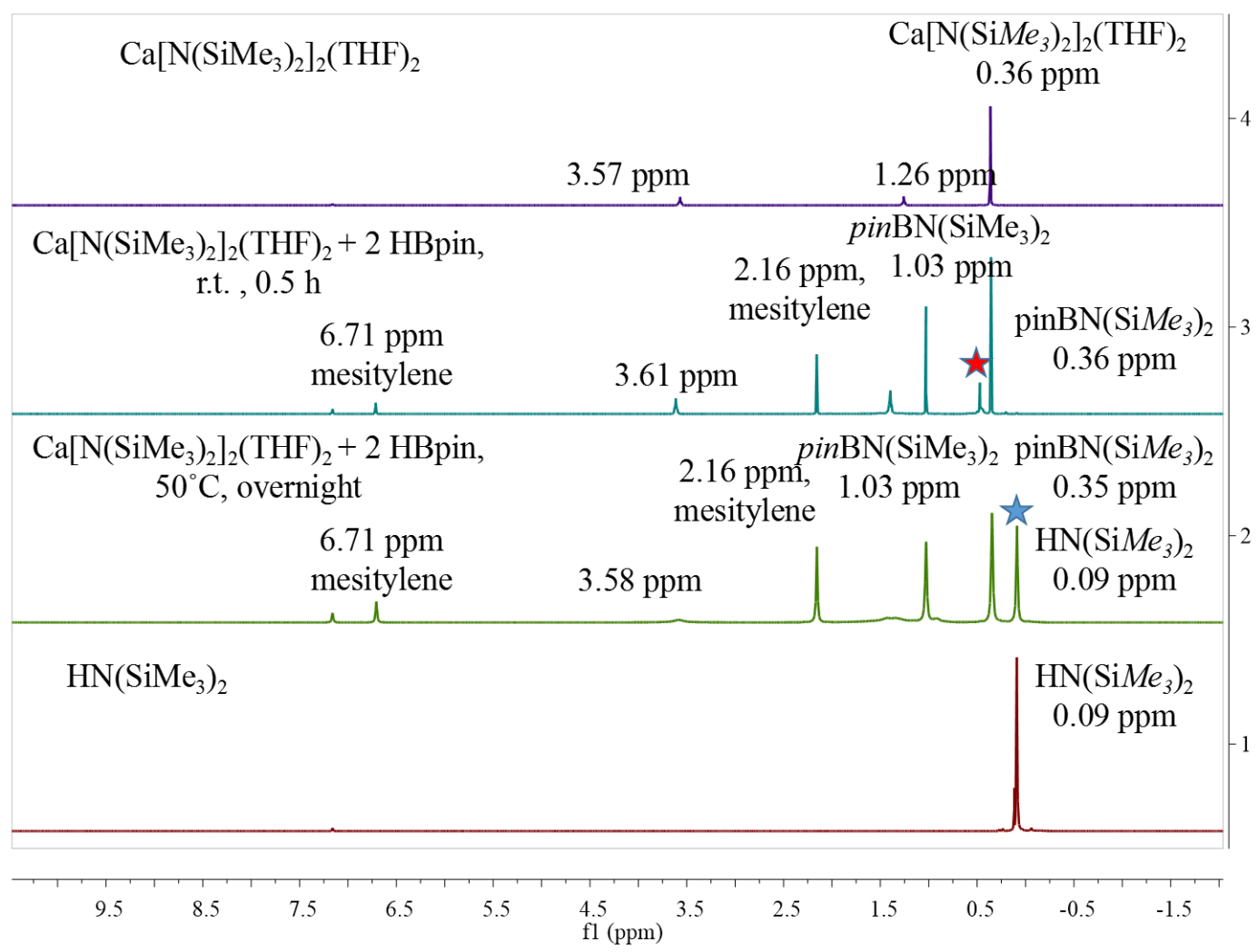

Figure S3. ${ }^{1} \mathrm{H}$ NMR stack $\left(\mathrm{C}_{6} \mathrm{D}_{6}\right)$ showing $\mathrm{HN}\left(\mathrm{SiMe}_{3}\right)_{2}, \mathrm{Ca}\left[\mathrm{N}\left(\mathrm{SiMe}_{3}\right)_{2}\right]_{2}(\mathrm{THF})_{2}$, $\operatorname{pinBN}\left(\mathrm{SiMe}_{3}\right)_{2}$ and $\mathrm{HN}\left(\mathrm{SiMe}_{3}\right)_{2}$ generated in situ from the reaction of $\mathrm{Ca}\left[\mathrm{N}\left(\mathrm{SiMe}_{3}\right)_{2}\right]_{2}(\mathrm{THF})_{2}$ with HBpin in 1:2 molar ratio at ambient temperature and 50 ${ }^{\circ} \mathrm{C}$ in $\mathrm{C}_{6} \mathrm{D}_{6}$. 


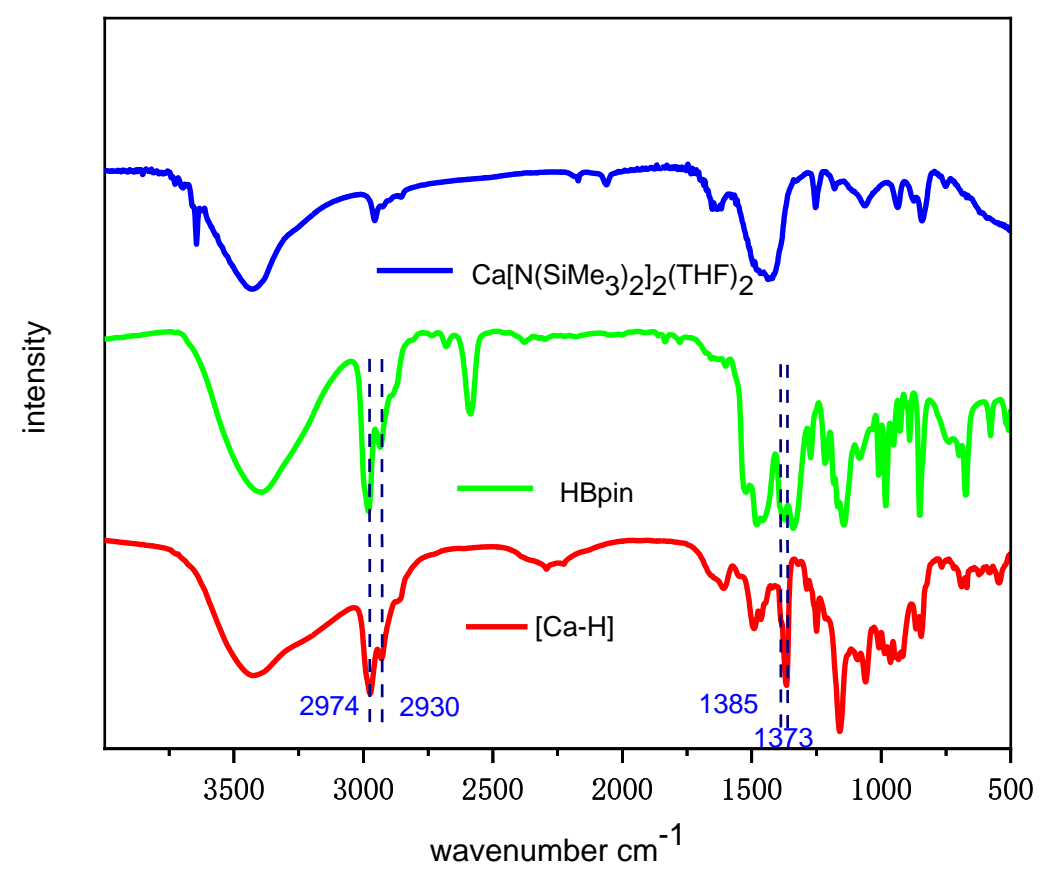

Figure S4. FT-IR spectroscopy of insoluble $[\mathrm{Ca}-\mathrm{H}]$ species, like $[\mathrm{BpinCaH}](\mathrm{KBr})$

7. Reaction of $\mathrm{Ca}\left[\mathrm{N}\left(\mathrm{SiMe}_{3}\right)_{2}\right]_{2}(\mathrm{THF})_{2}$ with $p$-methylbenzamide to understand catalytic active species

In a NMR tube, $\mathrm{Ca}\left[\mathrm{N}\left(\mathrm{SiMe}_{3}\right)_{2}\right]_{2}(\mathrm{THF})_{2} \quad(19 \quad \mathrm{mg}, \quad 0.0375 \quad \mathrm{mmol})$ and p-methylbenzamide (10 mg, $0.075 \mathrm{mmol})$ and mesitylene $(0.0375 \mathrm{mmol}, 5 \mu \mathrm{L})$ were combined in $\mathrm{C}_{6} \mathrm{D}_{6}(0.8 \mathrm{~mL})$ at $120{ }^{\circ} \mathrm{C}$. After $7 \mathrm{~h}$, the soluble product formed in situ was characterized by ${ }^{1} \mathrm{H}$ NMR spectroscopy. ${ }^{1} \mathrm{H}$ NMR (500 MHz, $\left.\mathrm{C}_{6} \mathrm{D}_{6}, \mathrm{ppm}\right): \delta 3.57$ (m, THF- $\left.\alpha-\mathrm{CH}_{2}\right), 1.42$ (m, THF- $\left.\beta-\mathrm{CH}_{2}\right), 0.10$ (s, $\left.\mathrm{HN}\left(\mathrm{SiMe}_{3}\right)_{2}\right)$ (Figure S5).

The precipitate was washed with hexane, and dried in vacuum and characterized by FT-IR spectroscopy.

$\left.\mathrm{Ca}\left[\mathrm{N}\left(\mathrm{SiMe}_{3}\right)_{2}\right]_{2}(\mathrm{THF})_{2}+2 \stackrel{\mathrm{C}_{6} \mathrm{D}_{6}}{120^{\circ} \mathrm{C}, 7 \mathrm{~h}} \mathrm{Ca}\left(\mathrm{NH}_{\mathrm{H}}^{\mathrm{O}}\right)-\mathrm{PhMe}\right)_{2}+2 \mathrm{HN}\left(\mathrm{SiMe}_{3}\right)_{2}+\mathrm{THF}$

Scheme S2. Reaction of $\mathrm{Ca}\left[\mathrm{N}\left(\mathrm{SiMe}_{3}\right)_{2}\right]_{2}(\mathrm{THF})_{2}$ with $p-\mathrm{MePhCONH}{ }_{2}$ in $\mathrm{C}_{6} \mathrm{D}_{6}$. 


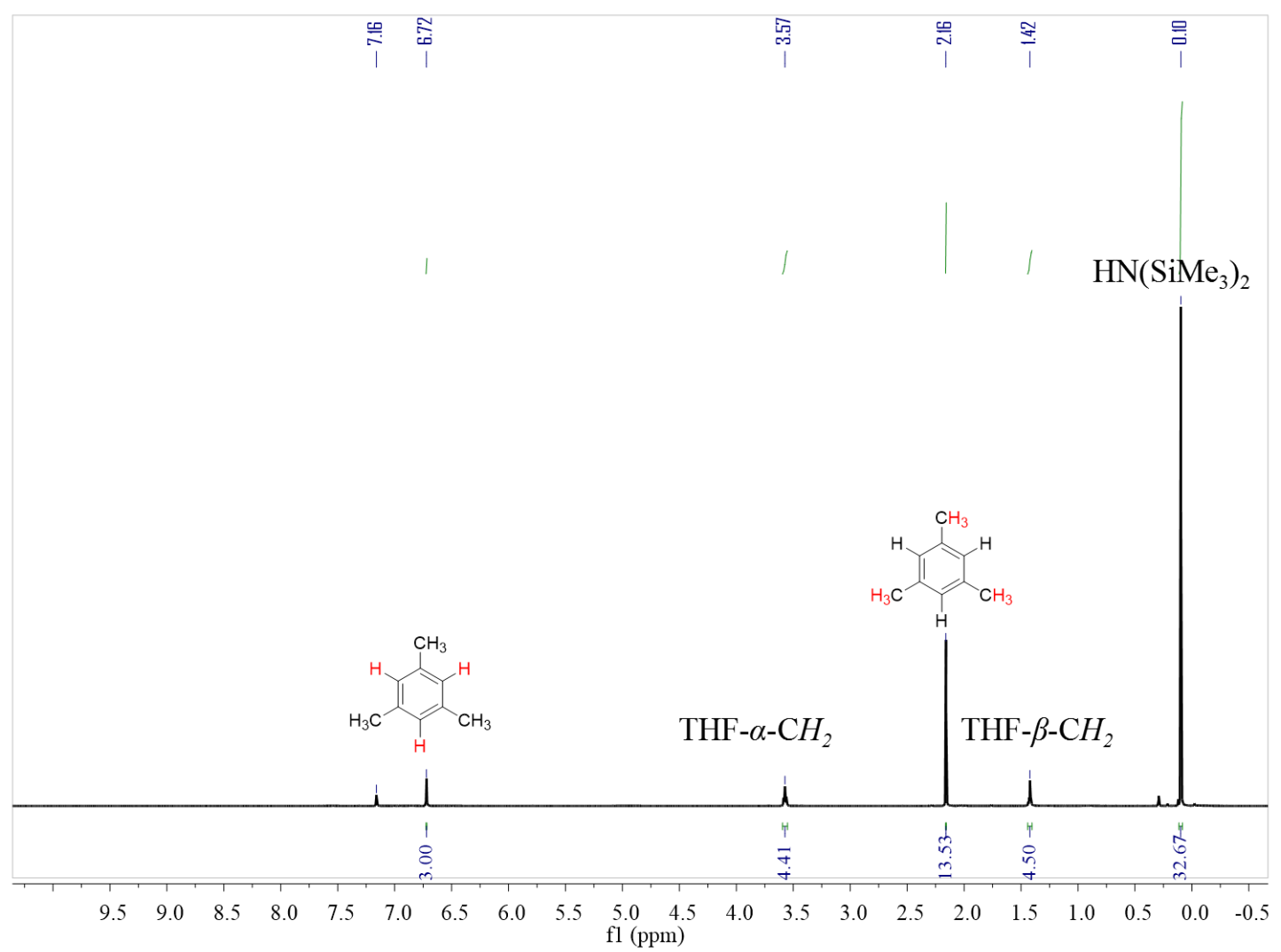

Figure S5. ${ }^{1} \mathrm{H}$ NMR spectrum of the soluble product generated in situ from $\mathrm{Ca}\left[\mathrm{N}\left(\mathrm{SiMe}_{3}\right)_{2}\right]_{2}(\mathrm{THF})_{2}$ and $p$-methylbenzamide in 1:2 molar ratio in $\mathrm{C}_{6} \mathrm{D}_{6}$.

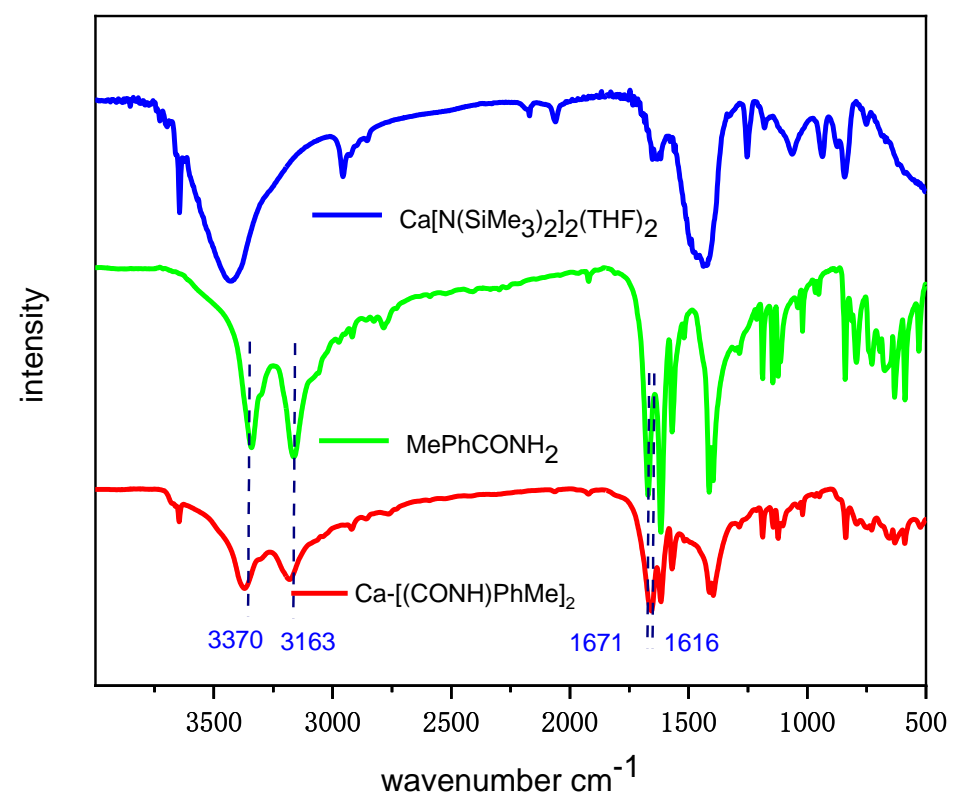

Figure S6. FT-IR spectroscopy of $\mathrm{Ca}[(\mathrm{CONH}) \mathrm{PhMe}]_{2}(\mathrm{THF})$ species $(\mathrm{KBr})$. 
8. Reaction of $p$-methylbenzamide with HBpin without catalyst and further workup

In a glovebox, $p$-methylbenzamide $(0.25 \mathrm{mmol})$, HBpin $(1.25 \mathrm{mmol}, 5$ equivalent $)$, and $\mathrm{C}_{6} \mathrm{D}_{6}(0.8 \mathrm{~mL})$ were added in a NMR tube. The reaction mixture was kept at ambient temperature overnight, and was characterized by ${ }^{1} \mathrm{H}$ NMR spectroscopy. ${ }^{1} \mathrm{H}$ NMR (400 MHz, $\left.\mathrm{C}_{6} \mathrm{D}_{6}, \mathrm{ppm}\right): \delta 10.43(\mathrm{~s}, 1 \mathrm{H},-\mathrm{CHPhMe}), 7.83$ (d, 2H, -CHPhMe), $7.66(\mathrm{~d}, 2 \mathrm{H},-\mathrm{COPhMe}), 6.92(\mathrm{~d}, 2 \mathrm{H},-\mathrm{CH} P h \mathrm{Me}), 6.85(\mathrm{~d}, 2 \mathrm{H},-\mathrm{COPhMe}), 6.71(\mathrm{~s}, 2 \mathrm{H}$, -NHBpin), 4.46 (s, 2H, $\left.H_{2}\right), 4.84-3.58$ (m, 1H, HBpin), 1.98 (d, 3H, -COPhMe), 1.97 (d, 3H, -CHPhMe), 1.12 (s, 12H, =NBpin), 1.08 (s, 12H, -NHBpin), $1.00(\mathrm{~s}, 12 \mathrm{H}$, HBpin) (Figure S7).

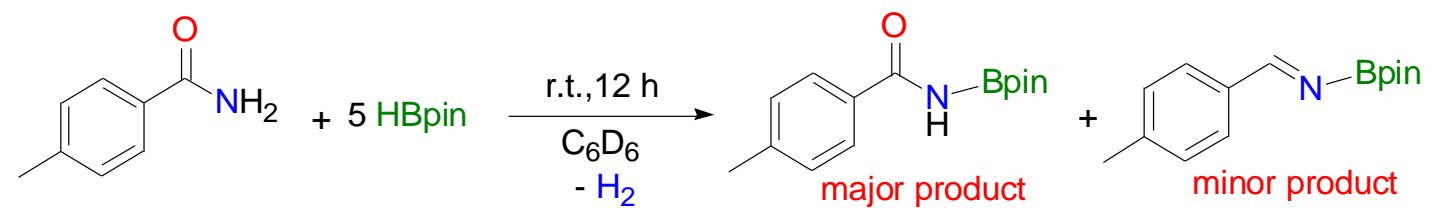

Scheme S3. Reaction of $p$-methylbenzamide with HBpin in $\mathrm{C}_{6} \mathrm{D}_{6}$. 


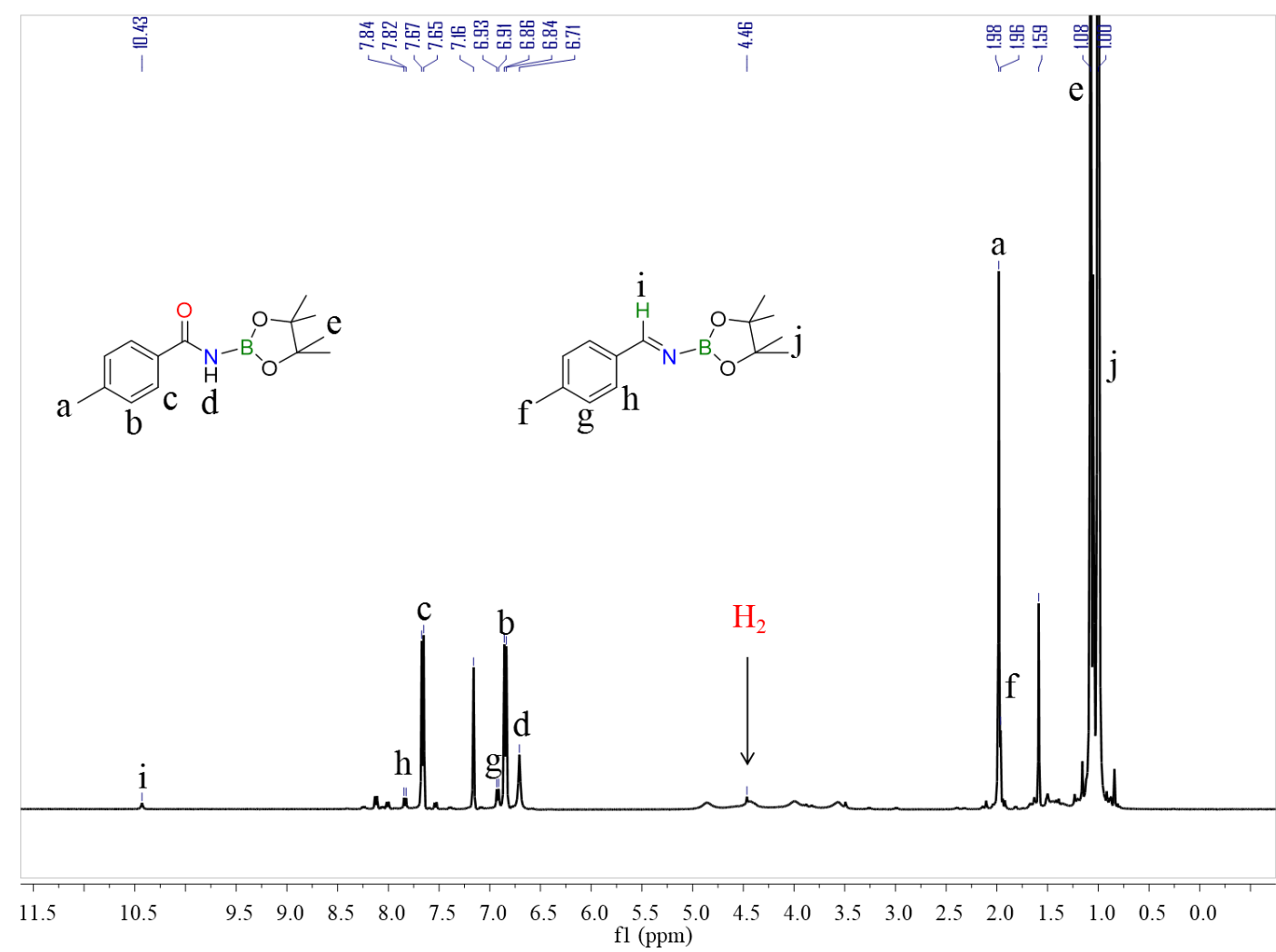

Figure S7. ${ }^{1} \mathrm{H}$ NMR spectrum of products formed in situ from the reaction of $p$-methylbenzamide with $\mathrm{HB}$ pin in $\mathrm{C}_{6} \mathrm{D}_{6}$.

9. Isolation and characterization of mono-borylated-amide intermediate p-MePhCONH(Bpin)

In a glovebox, $p$-methylbenzamide $(0.25 \mathrm{mmol})$, HBpin $(1.25 \mathrm{mmol}, 5$ equivalent $)$, and THF $(1 \mathrm{~mL})$ were added in a Schlenk flask. The reaction mixture was stirred at ambient temperature overnight. Removal of the volatiles under reduced pressure afforded a white powder, which was washed with $n$-hexane for three times. Drying up the residue gave a white solid. The borylated-amide compound $p$-MePhCONH(Bpin) was isolated by recrystallization from THF/hexane $(4 / 1 \mathrm{v} / \mathrm{v})$, and was characterized by ${ }^{1} \mathrm{H},{ }^{13} \mathrm{C}$, and ${ }^{11} \mathrm{~B}$ NMR spectroscopy (Figures S8-S10). 


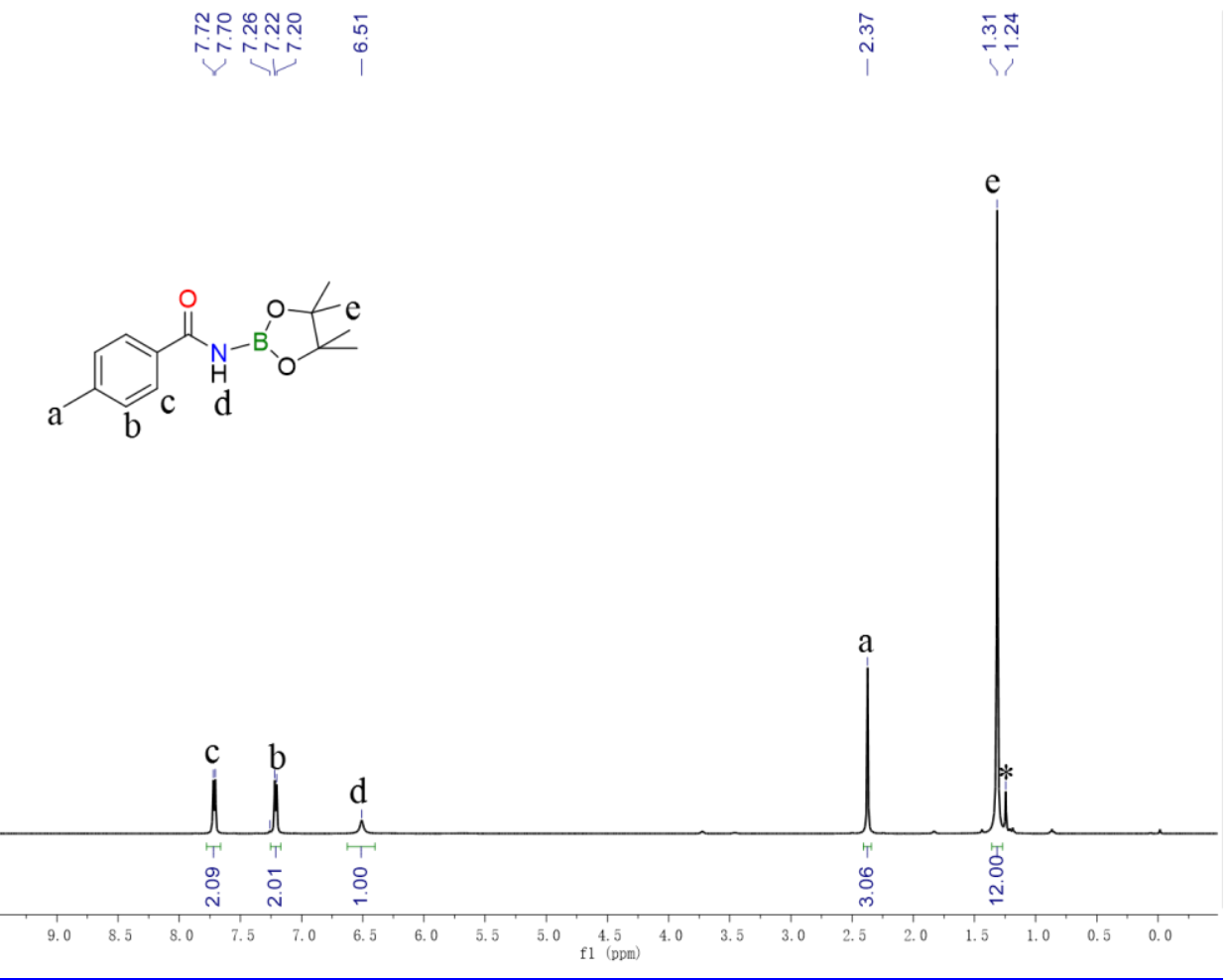

Figure S8. ${ }^{1} \mathrm{H}$ NMR spectrum of $p-\mathrm{MePhCONH}(\mathrm{Bpin})$ in $\mathrm{CDCl}_{3}$, * = residual $\mathrm{O}(\text { Bpin })_{2}$

${ }^{1} \mathrm{H}$ NMR $\left(500 \mathrm{MHz}, \mathrm{CDCl}_{3}, \mathrm{ppm}\right): \delta 7.71(\mathrm{~d}, J=8.0 \mathrm{~Hz}, 2 \mathrm{H},-\mathrm{COP} h \mathrm{Me}), 7.21(\mathrm{~d}, J=$ $7.9 \mathrm{~Hz}, 2 \mathrm{H},-\mathrm{COPhMe}), 6.51$ (s, 1H, -NHBpin), 2.37 (s, 3H, -COPhMe), 1.31 (s, 12H, -NHBpin). 


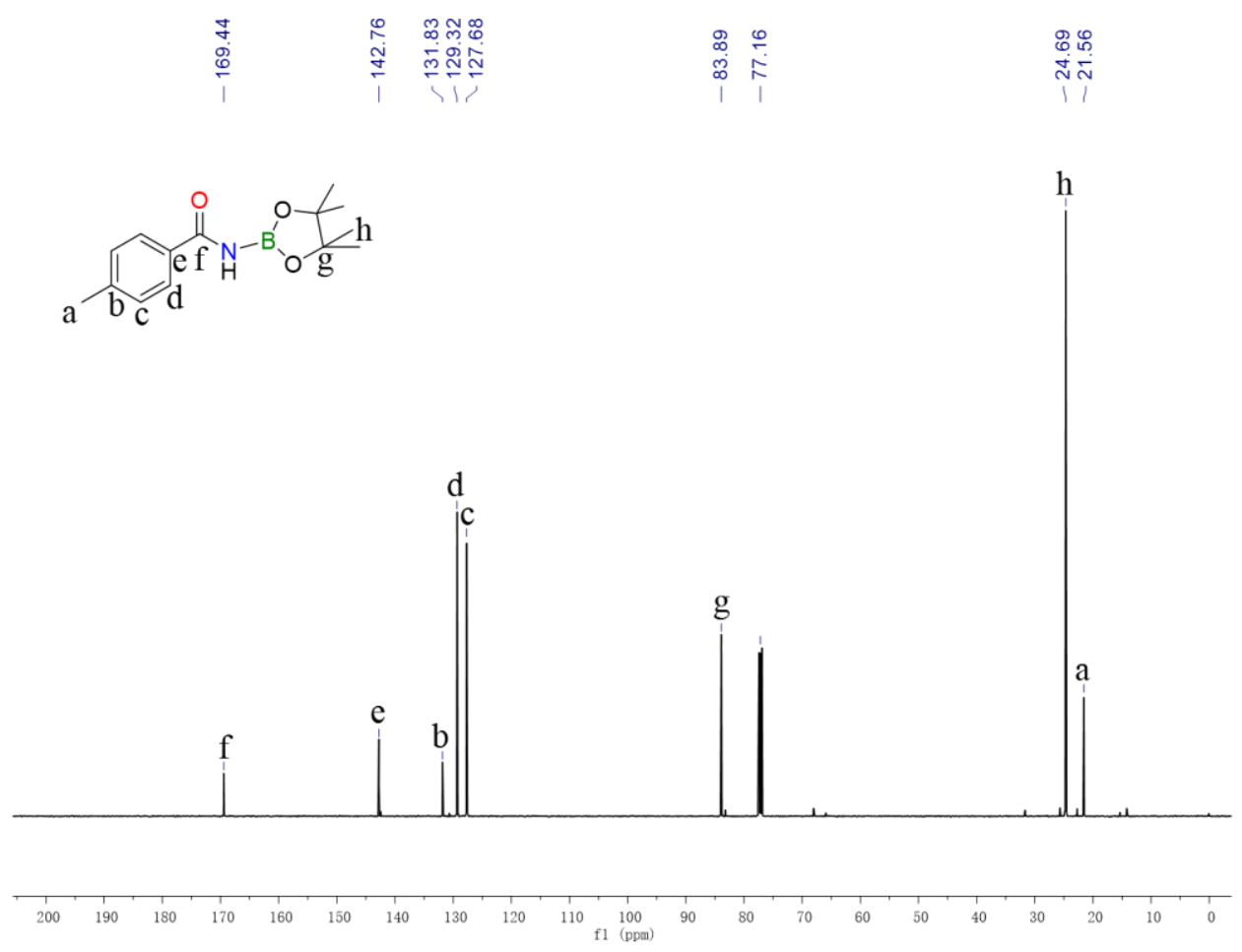

Figure S9. ${ }^{13} \mathrm{C}$ NMR spectrum of $p$-MePhCONH(Bpin) in $\mathrm{CDCl}_{3}$

${ }^{13} \mathrm{C} \mathrm{NMR}$ (126 MHz, $\left.\mathrm{CDCl}_{3}, \mathrm{ppm}\right): \delta 169.4$ (-COPhMe), 142.7 (-COPhMe), 131.8 (-COPhMe), 129.3 (-COPhMe), 127.7 (-COPhMe), 83.8 (Bpin), 24.7 (Bpin), 21.6 (-COPhMe).
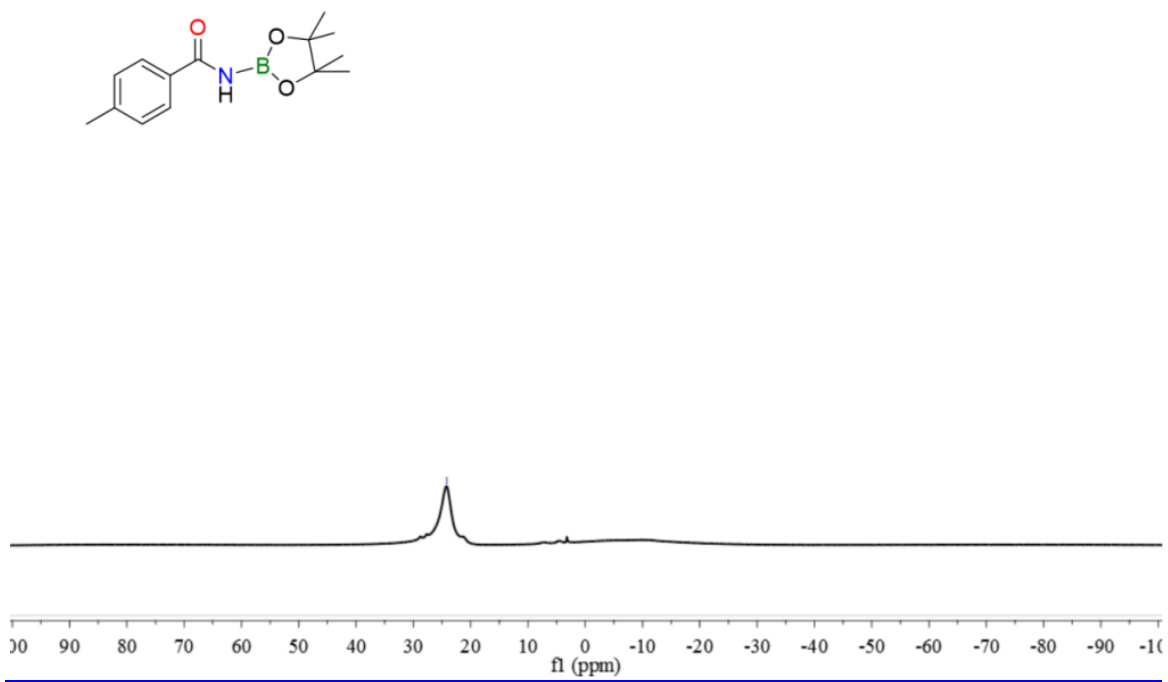

Figure S10. ${ }^{11} \mathrm{~B}$ NMR spectrum of $p$-MePhCONH(Bpin) in $\mathrm{CDCl}_{3}$.

${ }^{11} \mathrm{~B}$ NMR (160 MHz, $\left.\mathrm{CDCl}_{3}, \mathrm{ppm}\right): \delta 24.17$ (s, Bpin). 
10. Reaction of $p$-MePhCONH${ }_{2}$ with $\mathrm{HBpin}$ catalyzed by $\mathrm{Ca}\left[\mathrm{N}\left(\mathrm{SiMe}_{3}\right)_{2}\right]_{2}(\mathrm{THF})_{2}$ at $120{ }^{\circ} \mathrm{C}$.

In a Schlenk flask, $p-\mathrm{MePhCONH}_{2}(34 \mathrm{mg}, 0.25 \mathrm{mmol})$, HBpin $(0.625 \mathrm{mmol}, 5$ equivalent), $\mathrm{Ca}\left[\mathrm{N}\left(\mathrm{SiMe}_{3}\right)_{2}\right]_{2}(\mathrm{THF})_{2}(6.3 \mathrm{mg}, 0.0125 \mathrm{mmol})$ were combined in $\mathrm{C}_{6} \mathrm{D}_{6}$ $(0.8 \mathrm{~mL})$. The flask was taken out from the glovebox, and heated in an oil bath at 120 ${ }^{\circ} \mathrm{C}$. After $36 \mathrm{~h}$, the product formed in situ was characterized by ${ }^{1} \mathrm{H}$ NMR spectroscopy. ${ }^{1} \mathrm{H}$ NMR (500 MHz, $\left.\mathrm{C}_{6} \mathrm{D}_{6}\right): \delta 7.43\left(\mathrm{~d}, J=7.8 \mathrm{~Hz}, 2 \mathrm{H},-\mathrm{CH}_{2} P h \mathrm{Me}\right), 7.02(\mathrm{~d}, J=7.7$ $\left.\mathrm{Hz}, 2 \mathrm{H},-\mathrm{CH}_{2} \mathrm{PhMe}\right), 4.48$ (s, 2H, $\left.-\mathrm{CH}_{2} \mathrm{PhMe}\right), 2.14$ (s, 3H, $\left.-\mathrm{CH}_{2} \mathrm{PhMe}\right), 1.02$ (s, 24H, $\left.-\mathrm{N}(\mathrm{Bpin})_{2}\right)$.<smiles>Cc1ccc(C(N)=O)cc1</smiles><smiles>Cc1ccc(CN(Cc2ccccc2)Cc2ccccc2)cc1</smiles>

Scheme S4. Reaction of $p-\mathrm{MePhCONH}_{2}$ with HBpin catalyzed by $\mathrm{Ca}\left[\mathrm{N}\left(\mathrm{SiMe}_{3}\right)_{2}\right]_{2}(\mathrm{THF})_{2}$ at $120^{\circ} \mathrm{C}$.

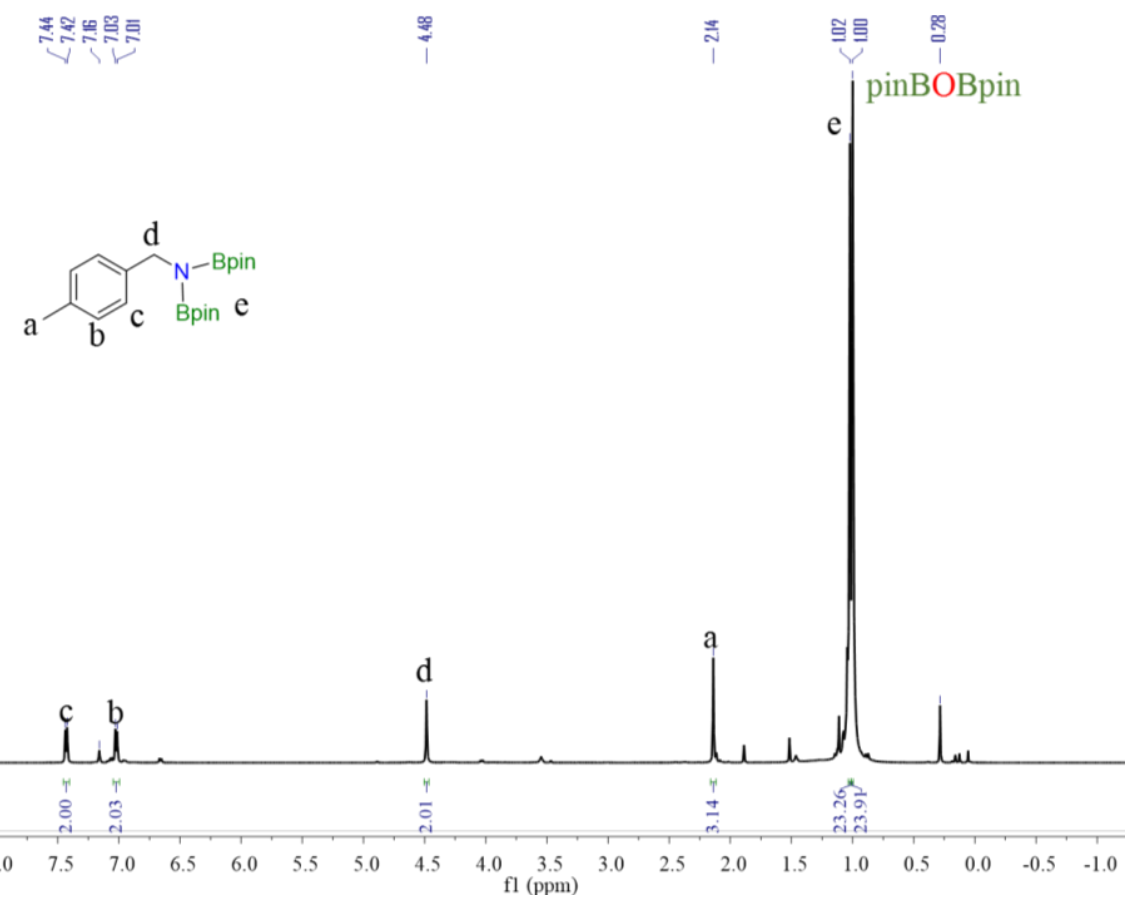


Figure S11. ${ }^{1} \mathrm{H}$ NMR spectrum of the product from the reaction of $p-\mathrm{MePhCONH}_{2}$ with $\mathrm{HBpin}$ catalyzed by $\mathrm{Ca}\left[\mathrm{N}\left(\mathrm{SiMe}_{3}\right)_{2}\right]_{2}(\mathrm{THF})_{2}$ at $120^{\circ} \mathrm{C}$.

\section{Reaction of $p$-MePhCONH(Bpin) with HBpin catalyzed by} $\mathrm{Ca}\left[\mathrm{N}\left(\mathrm{SiMe}_{3}\right)_{2}\right]_{2}(\mathrm{THF})_{2}$ at ambient temperature.

In a Schlenk flask, $p$-MePhCONH(Bpin) $(65 \mathrm{mg}, 0.25 \mathrm{mmol}), \mathrm{HB}$ in $(0.75 \mathrm{mmol}, 3$ equivalent), $\mathrm{Ca}\left[\mathrm{N}\left(\mathrm{SiMe}_{3}\right)_{2}\right]_{2}(\mathrm{THF})_{2}(6.3 \mathrm{mg}, 0.0125 \mathrm{mmol})$, were combined in THF (2 mL). The reaction mixture was stirred at ambient temperature overnight. Removal of the volatiles under reduced pressure afforded a white powder, which was washed with $n$-hexane for three times. Drying up the residue gave a white solid which was characterized by ${ }^{1} \mathrm{H}$ NMR spectroscopy. ${ }^{1} \mathrm{H}$ NMR (500 MHz, $\mathrm{CDCl}_{3}, \mathrm{ppm}$ ): $\delta 10.28$ (s, 1H, $p$-MePhCHNBpin), 8.05 (d, J = 8.2 Hz, 2H, p-MePhCHNBpin), 7.83 (d, J = 8.2 Hz, 2H, $p$-MePhCONH(Bpin)), 7.43 (d, J = 7.9 Hz, 2H, p-MePhCHNBpin), 7.33 (d, J $=7.9 \mathrm{~Hz}, 2 \mathrm{H}, p-\mathrm{Me} P h \mathrm{CONH}(\mathrm{Bpin})), 6.63$ (s, 1H, $p$-MePhCONH(Bpin)), 2.55 (s, 3H, p-MePhCHNBpin), 2.45 (s, 3H, p-MePhCONH(Bpin)).

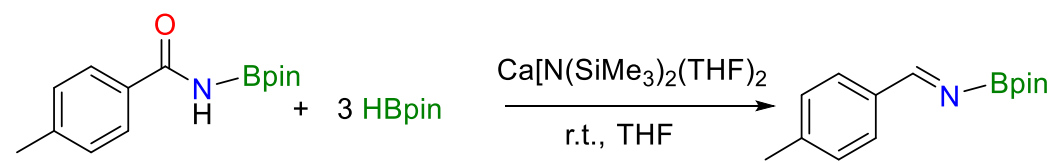

Scheme S5. Reaction of p-MePhCONH(Bpin) with HBpin catalyzed by $\mathrm{Ca}\left[\mathrm{N}\left(\mathrm{SiMe}_{3}\right)_{2}\right]_{2}(\mathrm{THF})_{2}$ at ambient temperature. 


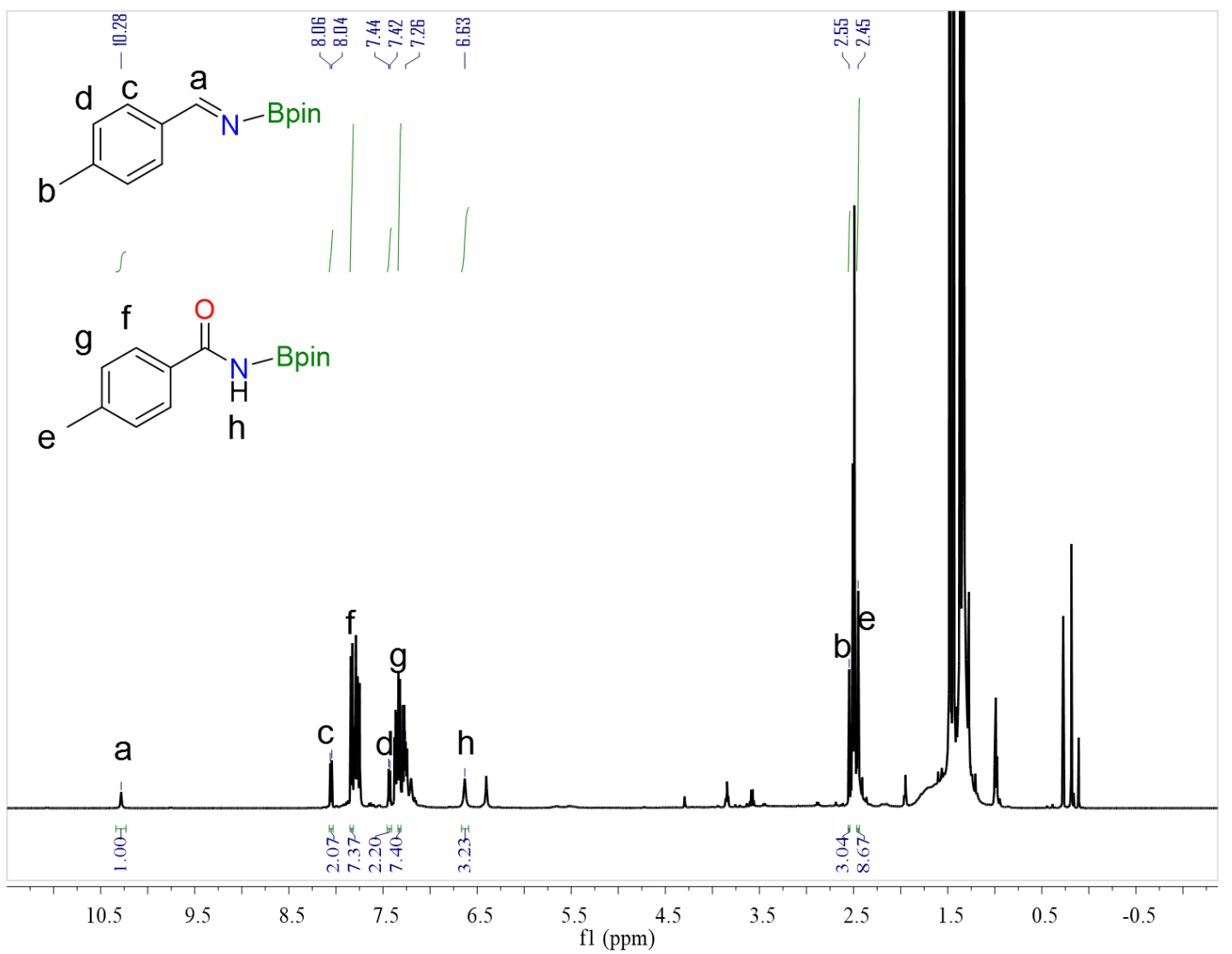

Figure S12. ${ }^{1} \mathrm{H}$ NMR spectrum of the imine from the reaction of p-MePhCONH(Bpin) with $\mathrm{HBpin}$ catalyzed by $\mathrm{Ca}\left[\mathrm{N}\left(\mathrm{SiMe}_{3}\right)_{2}\right]_{2}(\mathrm{THF})_{2}$ at ambient temperature. 


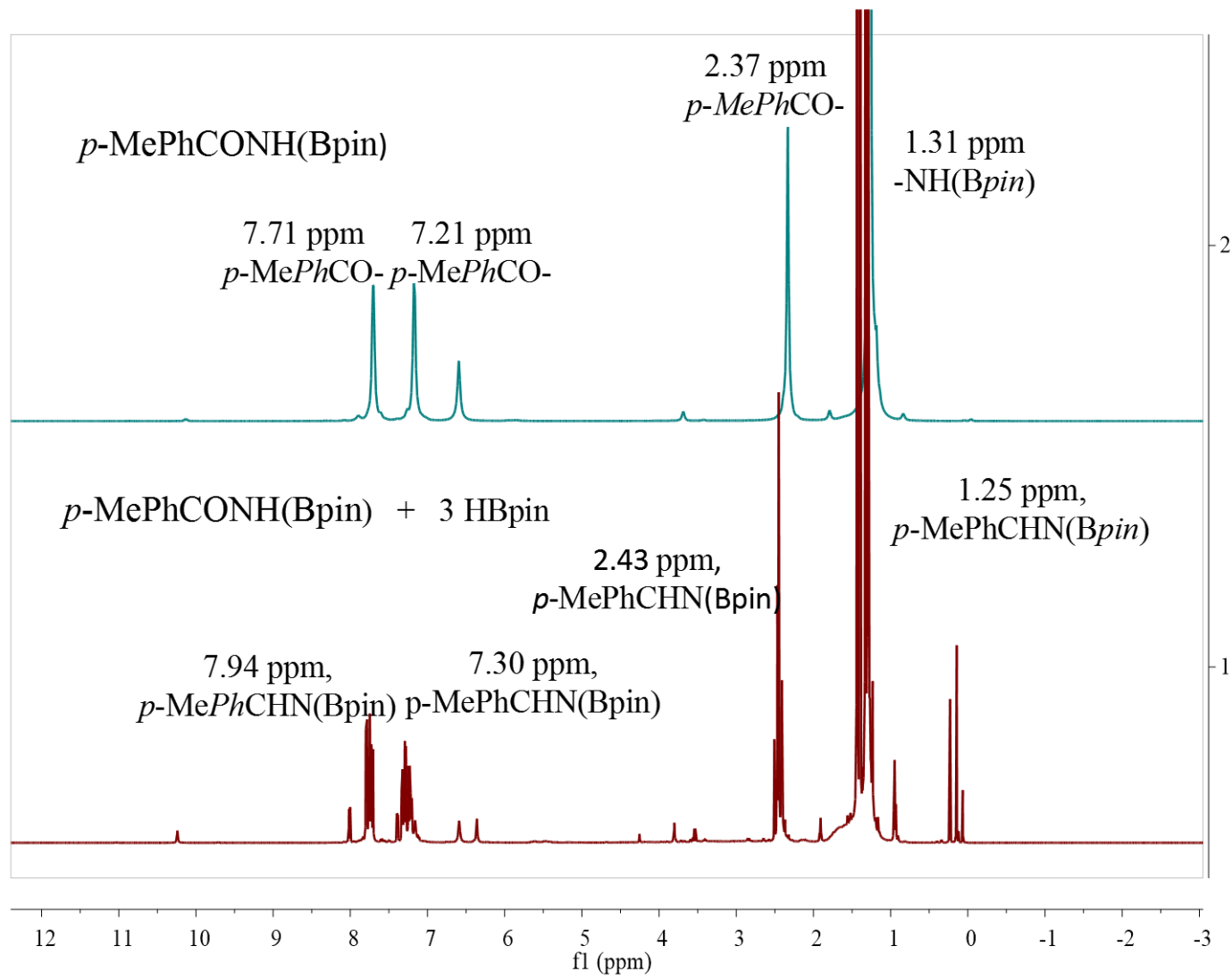

Figure S13. ${ }^{1} \mathrm{H}$ NMR stack $\left(\mathrm{CDCl}_{3}\right)$ showing the imine from the reaction of p-MePhCONH(Bpin) with HBpin catalyzed by $\mathrm{Ca}\left[\mathrm{N}\left(\mathrm{SiMe}_{3}\right)_{2}\right]_{2}(\mathrm{THF})_{2}$ at ambient temperature.

\section{Reaction of $p$-MePhCONH(Bpin) with HBpin catalyzed by}

$\mathrm{Ca}\left[\mathrm{N}\left(\mathrm{SiMe}_{3}\right)_{2}\right]_{2}(\mathrm{THF})_{2}$ at elevated temperature $\left(120^{\circ} \mathrm{C}\right)$.

In a J. Young type, PTFE-valved NMR tube, $p$-MePhCONH(Bpin) (65 mg, 0.25 mmol), HBpin (0.625 mmol, 5 equivalent $), \mathrm{Ca}\left[\mathrm{N}\left(\mathrm{SiMe}_{3}\right)_{2}\right]_{2}(\mathrm{THF})_{2}(6.3 \mathrm{mg}, 0.0125$ mmol), and mesitylene $(0.07 \mathrm{mmol}, 9.25 \mu \mathrm{L})$ were combined in $\mathrm{C}_{6} \mathrm{D}_{6}(0.8 \mathrm{~mL})$. The NMR tube was taken out from the glovebox, and heated in an oil bath at $120{ }^{\circ} \mathrm{C}$. After $36 \mathrm{~h}$, the reaction mixture was subjected to ${ }^{1} \mathrm{H}$ NMR spectroscopy.

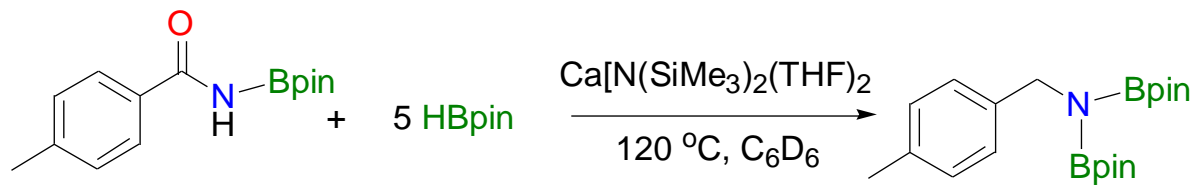


Scheme S6. Reaction of $p$-MePhCONH(Bpin) with HBpin catalyzed by $\mathrm{Ca}\left[\mathrm{N}\left(\mathrm{SiMe}_{3}\right)_{2}\right]_{2}(\mathrm{THF})_{2}$ at $120^{\circ} \mathrm{C}$.

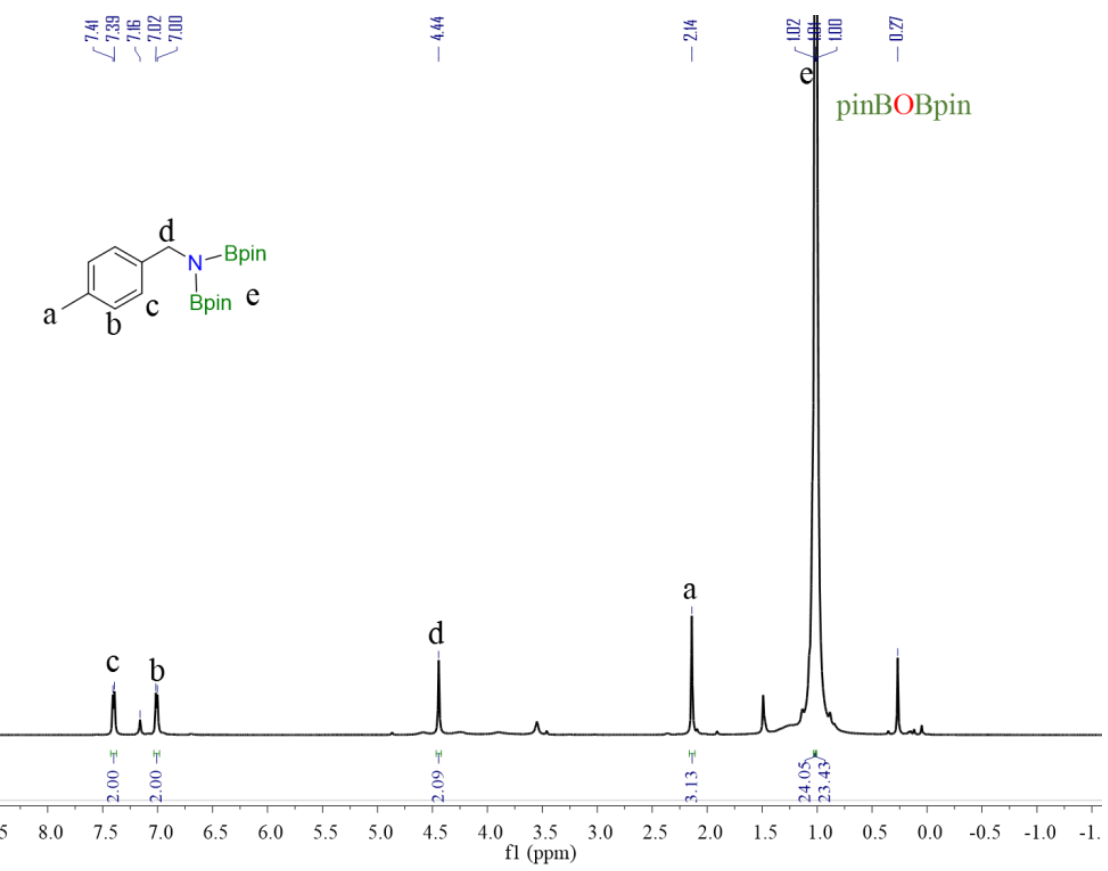

Figure S14. ${ }^{1}$ H NMR spectrum of the product generated in situ from the reaction of p-MePhCONH(Bpin) with HBpin catalyzed by $\mathrm{Ca}\left[\mathrm{N}\left(\mathrm{SiMe}_{3}\right)_{2}\right]_{2}(\mathrm{THF})_{2}$ at $120{ }^{\circ} \mathrm{C}$.
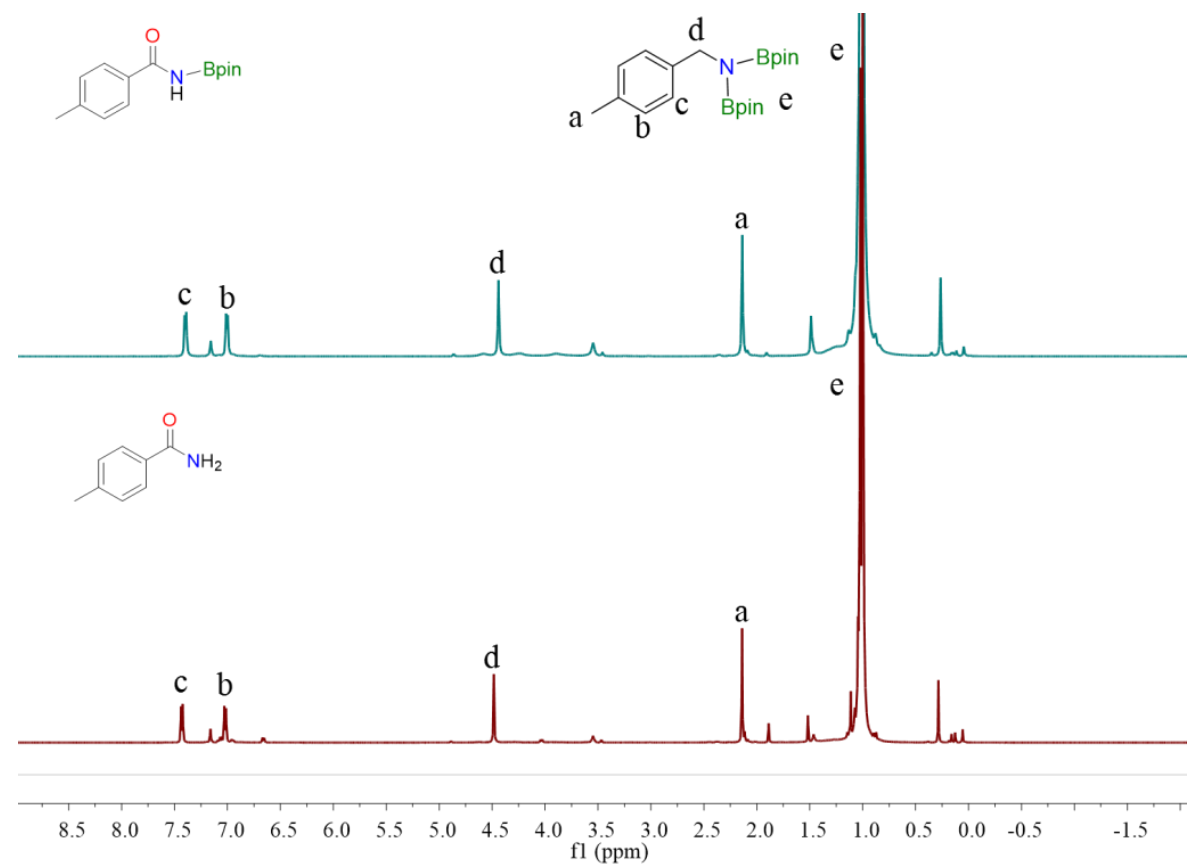

Figure S15. ${ }^{1} \mathrm{H}$ NMR stack $\left(\mathrm{C}_{6} \mathrm{D}_{6}\right)$ showing the product generated from the reaction of $p$-MePhCONH $2 / p-\mathrm{MePhCONH}(\mathrm{Bpin}) \quad$ with $\mathrm{HBpin}$ catalyzed by $\mathrm{Ca}\left[\mathrm{N}\left(\mathrm{SiMe}_{3}\right)_{2}\right]_{2}(\mathrm{THF})_{2}$ at $120^{\circ} \mathrm{C}$. 


\section{Characterization of amines.}

Amide reduction products were characterized by ${ }^{1} \mathrm{H}$ NMR. Products were converted to amine $\bullet \mathrm{HCls}$ (unless otherwise noted).

1. $\stackrel{\mathrm{N}^{\prime}}{\mathrm{I}}(99 \%)$

${ }^{1} \mathrm{H}$ NMR (400 MHz, $\left.\mathrm{C}_{6} \mathrm{D}_{6}, \mathrm{ppm}\right): \delta 2.02$ (s, 9H, NMe 3 ), 1.01 (s, 24H, nipBOBpin).

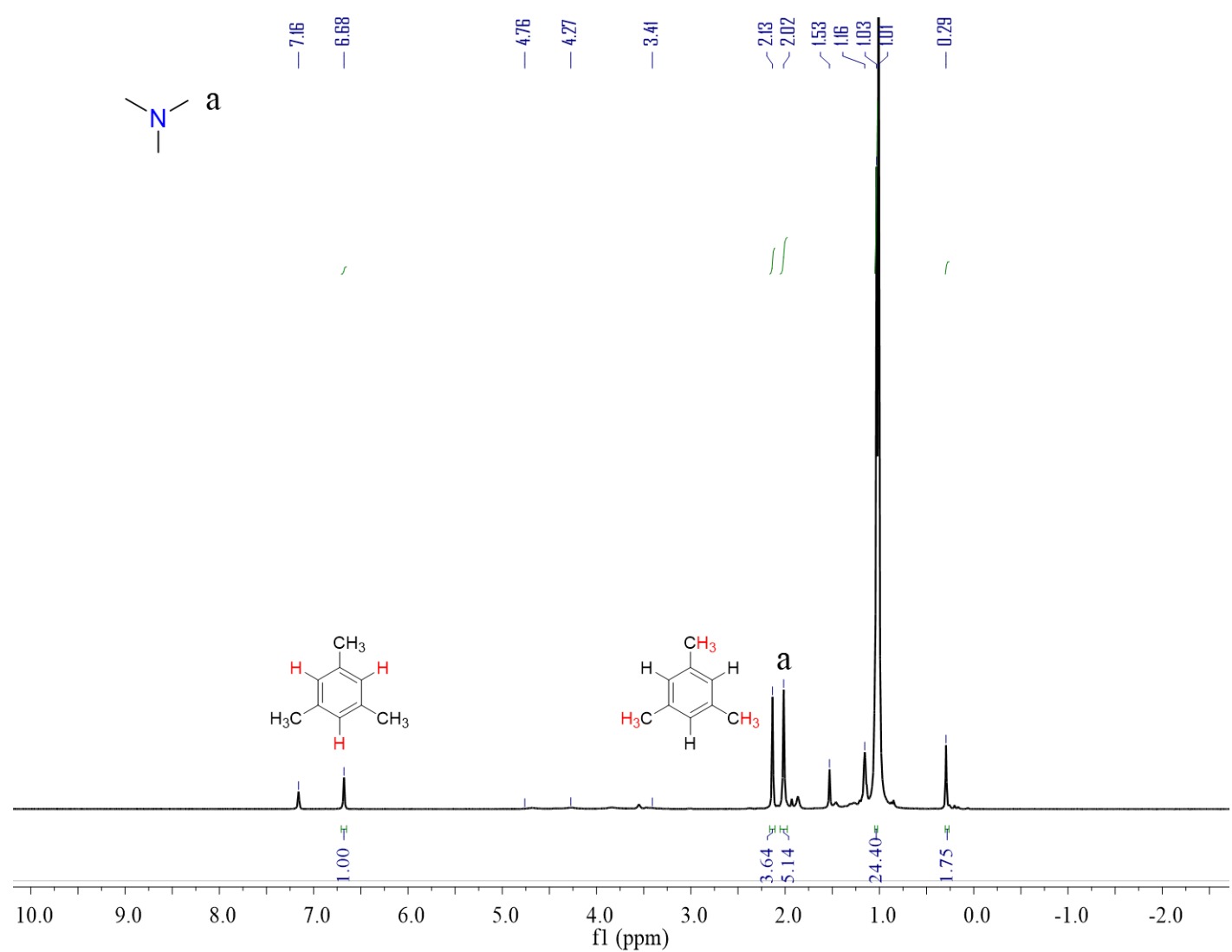

Figure S16. ${ }^{1} \mathrm{H}$ NMR spectrum of 1 in $\mathrm{C}_{6} \mathrm{D}_{6}$ (400 MHz, ppm). 
$2 . \widehat{N}^{-}(75 \%)$

${ }^{1} \mathrm{H}$ NMR (400 MHz, $\left.\mathrm{C}_{6} \mathrm{D}_{6}, \mathrm{ppm}\right): \delta 2.38\left(\mathrm{q}, \mathrm{J}=14.6 \mathrm{~Hz}, 2 \mathrm{H},-\mathrm{CH}_{2} \mathrm{CH}_{3}\right), 2.05(\mathrm{~s}, 6 \mathrm{H}$, $\left.-\mathrm{N}\left(\mathrm{CH}_{3}\right)_{2}\right), 1.92\left(\mathrm{~s}, 3 \mathrm{H},-\mathrm{CH}_{2} \mathrm{CH}_{3}\right)$.

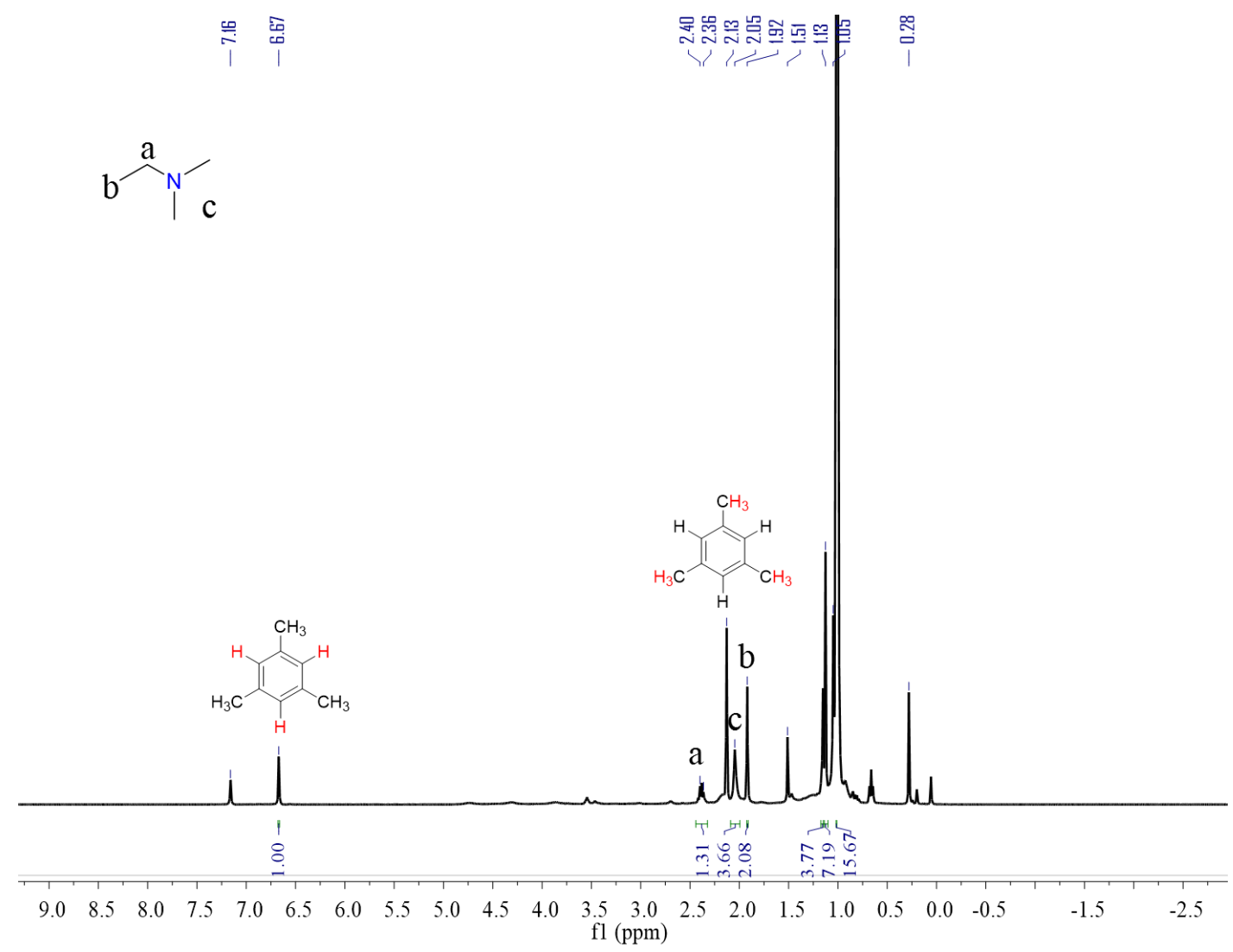

Figure S17. ${ }^{1} \mathrm{H}$ NMR spectrum of 2 in $\mathrm{C}_{6} \mathrm{D}_{6}(400 \mathrm{MHz}, \mathrm{ppm})$. 
3.

${ }^{1} \mathrm{H}$ NMR (500 MHz, $\left.\mathrm{C}_{6} \mathrm{D}_{6}, \mathrm{ppm}\right): \delta 7.28\left(\mathrm{~d}, \mathrm{~J}=7.5 \mathrm{~Hz}, 2 \mathrm{H},-\mathrm{CH}_{2} P h\right), 7.16-7.13(\mathrm{~m}$, $\left.2 \mathrm{H},-\mathrm{CH}_{2} \mathrm{Ph}\right), 7.09\left(\mathrm{~d}, \mathrm{~J}=7.4 \mathrm{~Hz}, 1 \mathrm{H},-\mathrm{CH}_{2} \mathrm{Ph}\right), 5.87-5.79(\mathrm{~m}, 1 \mathrm{H}$, $\left.-\mathrm{N}\left(\mathrm{CH}_{3}\right) \mathrm{CH}_{2} \mathrm{CHCH}_{2}\right), 5.02\left(\mathrm{t}, \mathrm{J}=7.5 \mathrm{~Hz}, 1 \mathrm{H},-\mathrm{N}\left(\mathrm{CH}_{3}\right) \mathrm{CH}_{2} \mathrm{CHCH}_{2}\right), 5.01(\mathrm{t}, \mathrm{J}=22.8$ $\left.\mathrm{Hz}, 1 \mathrm{H},-\mathrm{N}\left(\mathrm{CH}_{3}\right) \mathrm{CH}_{2} \mathrm{CHCH}_{2}\right), 3.34\left(\mathrm{~s}, 2 \mathrm{H},-\mathrm{N}\left(\mathrm{CH}_{3}\right) \mathrm{CH}_{2} \mathrm{CHCH}_{2}\right), 2.87(\mathrm{~d}, \mathrm{~J}=6.1 \mathrm{~Hz}$, $\left.2 \mathrm{H},-\mathrm{CH}_{2} \mathrm{Ph}\right), 2.05\left(\mathrm{~s}, 3 \mathrm{H},-\mathrm{N}\left(\mathrm{CH}_{3}\right) \mathrm{CH}_{2} \mathrm{CHCH}_{2}\right)$.

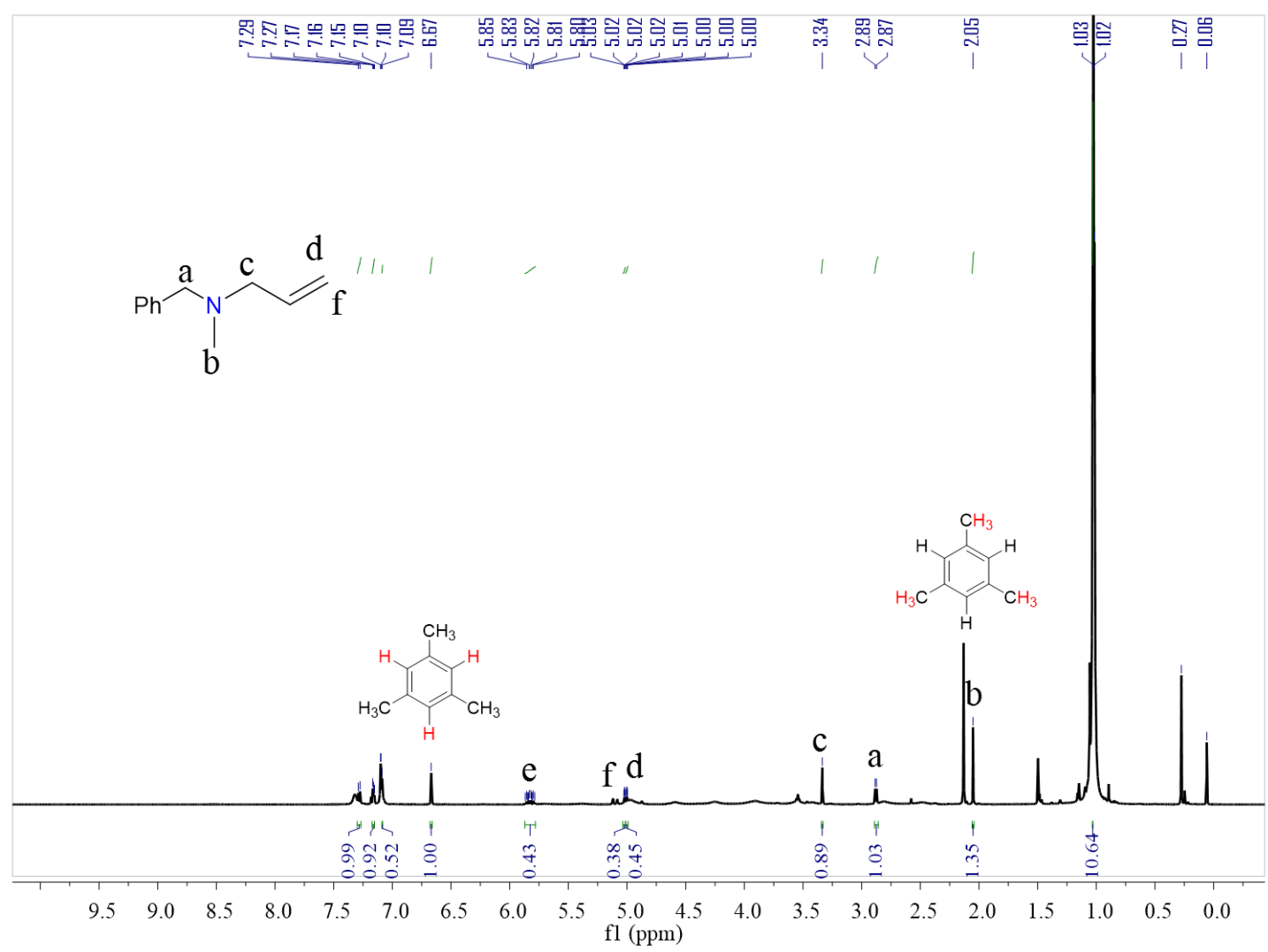

Figure S18. ${ }^{1} \mathrm{H}$ NMR spectrum of 3 in $\mathrm{C}_{6} \mathrm{D}_{6}(500 \mathrm{MHz}, \mathrm{ppm})$. 
4. $\underset{\mathrm{N}}{\mathrm{Bpin}}(99 \%)$

${ }^{1} \mathrm{H}$ NMR (500 MHz, $\left.\mathrm{C}_{6} \mathrm{D}_{6}, \mathrm{ppm}\right): 2.92$ (q, J = 6.9 Hz, 4H, N( $\left.\left.\mathrm{CH}_{2} \mathrm{CH}_{3}\right)_{2} \mathrm{Bpin}\right), 1.07$ (s, 12H, $\left.\mathrm{N}\left(\mathrm{CH}_{2} \mathrm{CH}_{3}\right)_{2} \mathrm{Bpin}\right), 0.94\left(\mathrm{t}, \mathrm{J}=7.0 \mathrm{~Hz}, 6 \mathrm{H}, \mathrm{N}\left(\mathrm{CH}_{2} \mathrm{CH}_{3}\right)_{2} \mathrm{Bpin}\right)$.

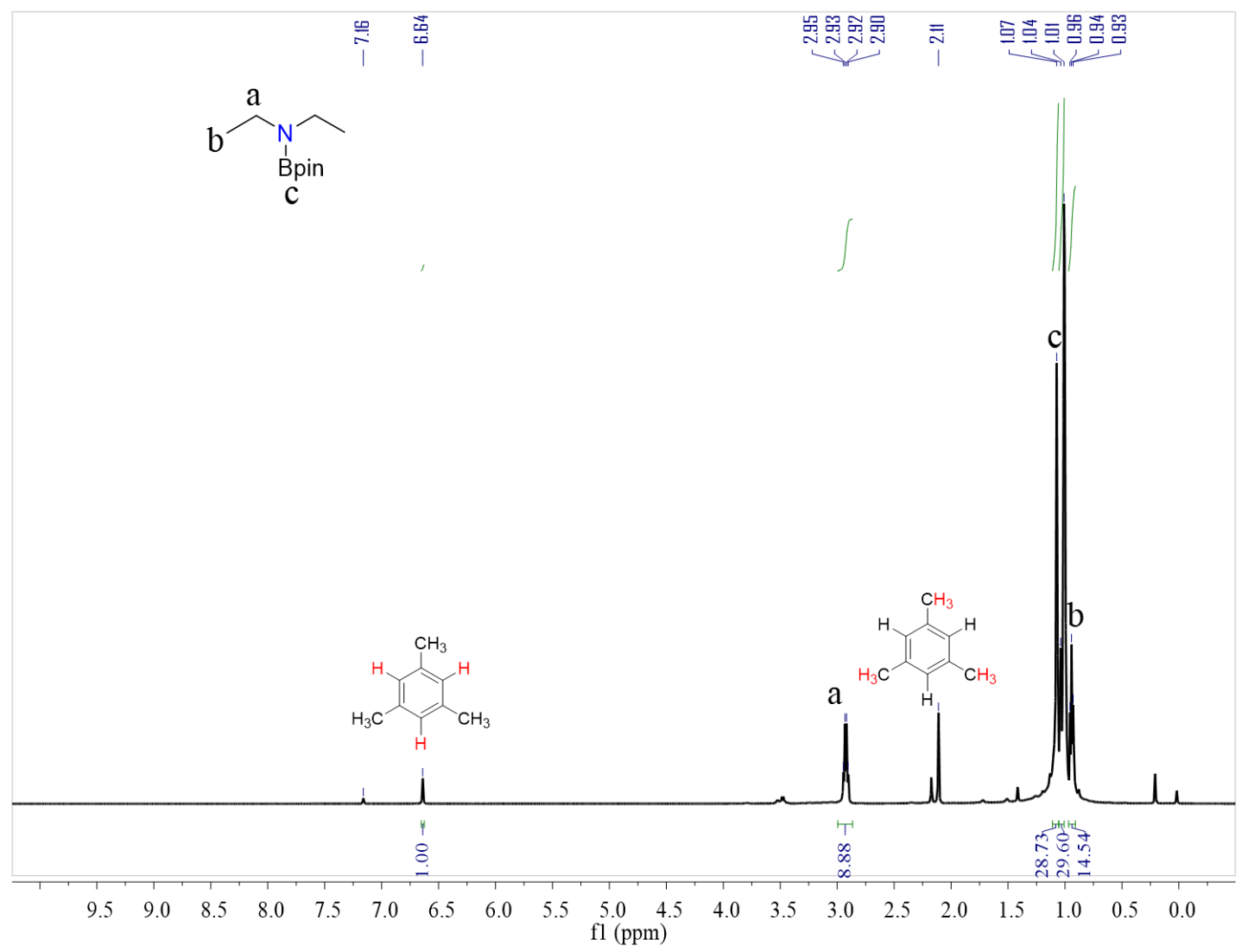

Figure S19. ${ }^{1} \mathrm{H}$ NMR spectrum of 4 in $\mathrm{C}_{6} \mathrm{D}_{6}(500 \mathrm{MHz}, \mathrm{ppm})$. 
5. $\overbrace{}^{N^{\text {Bpin }}}(99 \%)$

${ }^{1} \mathrm{H}$ NMR (400 MHz, $\left.\mathrm{C}_{6} \mathrm{D}_{6}, \mathrm{ppm}\right): \delta 3.09\left(\mathrm{t}, J=6.0 \mathrm{~Hz}, 4 \mathrm{H},-\mathrm{NC}_{6} H_{10}\right), 1.53(\mathrm{~s}, 4 \mathrm{H}$, $\left.-\mathrm{NC}_{6} H_{10}\right), 1.43\left(\mathrm{~s}, 4 \mathrm{H},-\mathrm{NC}_{6} H_{10}\right), 1.10(\mathrm{~s}, 12 \mathrm{H}, \mathrm{B} p i n)$.

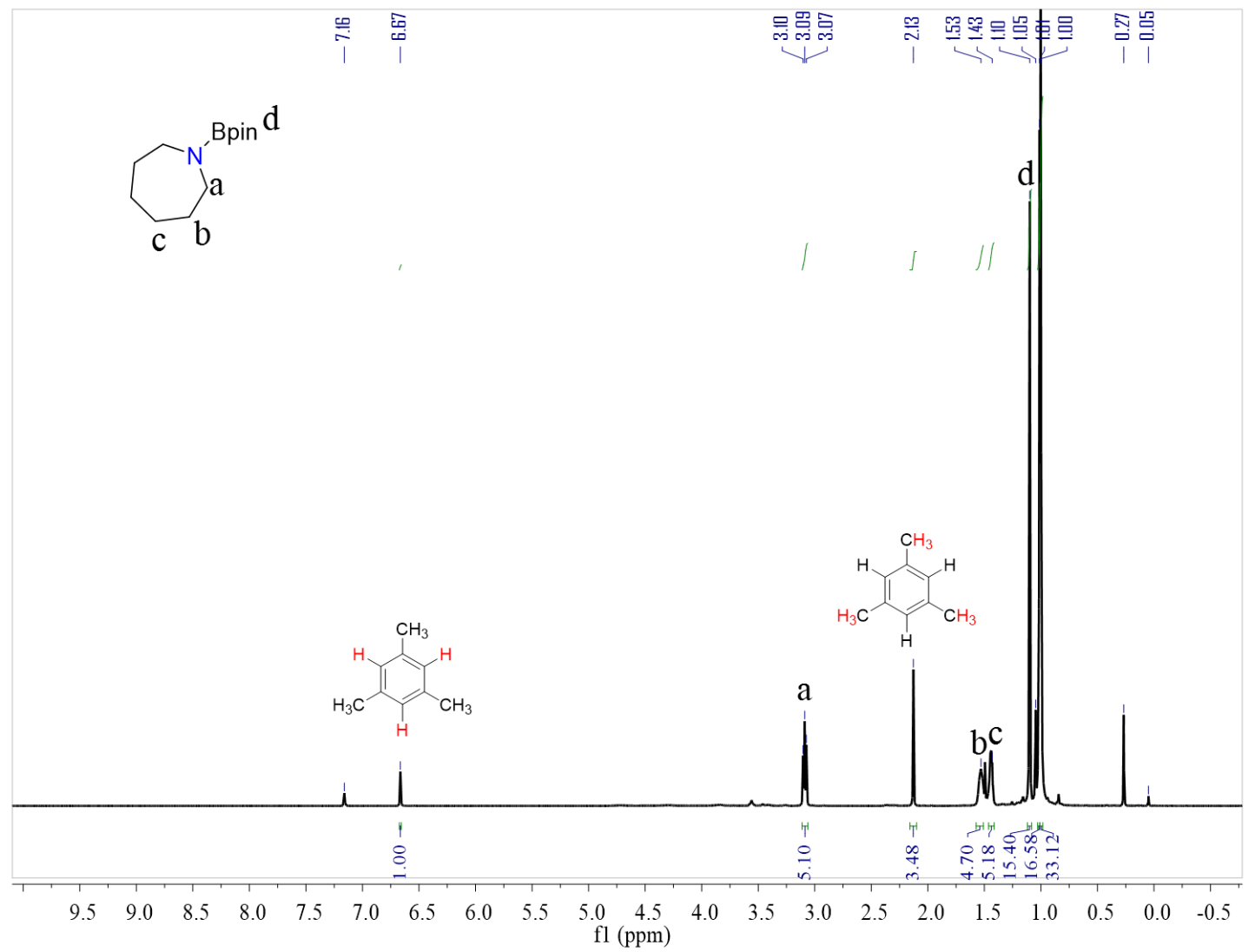

Figure S20. ${ }^{1} \mathrm{H}$ NMR spectrum of 5 in $\mathrm{C}_{6} \mathrm{D}_{6}(400 \mathrm{MHz}, \mathrm{ppm})$. 
$6 . \overbrace{\substack{N^{\prime} \\ \text { Bpin }}}^{N_{(99 \%)}}$

${ }^{1} \mathrm{H}$ NMR (500 MHz, $\left.\mathrm{C}_{6} \mathrm{D}_{6}, \mathrm{ppm}\right): \delta 7.20\left(\mathrm{~d}, J=7.5 \mathrm{~Hz}, 2 \mathrm{H},-\mathrm{CH}_{2} \mathrm{Ph}\right), 7.14(\mathrm{~d}, J=6.4$

$\left.\mathrm{Hz}, 2 \mathrm{H},-\mathrm{CH}_{2} \mathrm{Ph}\right), 7.05\left(\mathrm{t}, J=7.0 \mathrm{~Hz}, 1 \mathrm{H},-\mathrm{CH}_{2} \mathrm{Ph}\right), 4.07\left(\mathrm{~s}, 2 \mathrm{H},-\mathrm{CH}_{2} \mathrm{Ph}\right), 2.50(\mathrm{~s}, 3 \mathrm{H}$,

-N(Me)Bpin), 1.11 (s, 12H, -N(Me)Bpin), 1.01 (s, 24H, nipBOBpin).

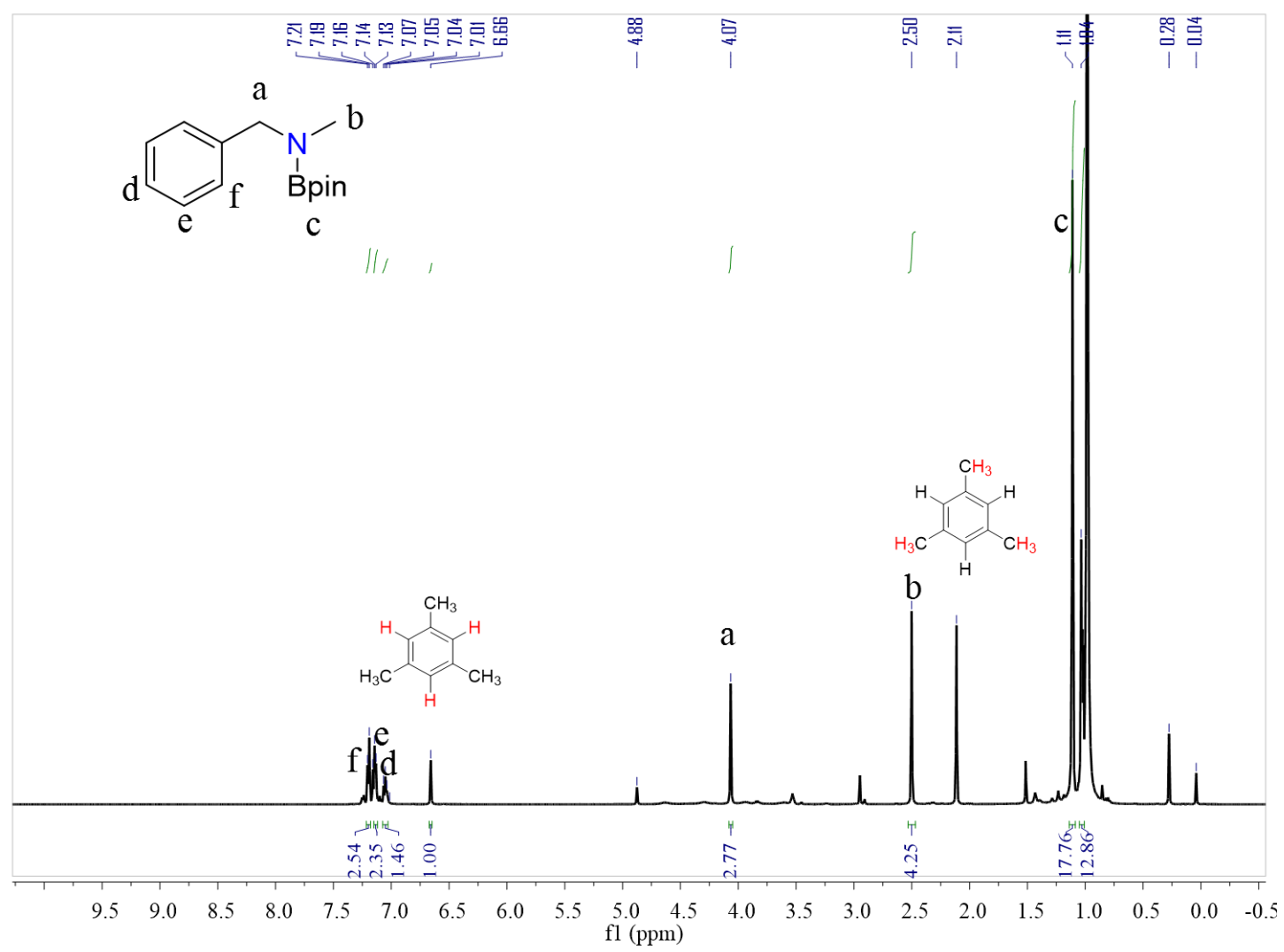

Figure S21. ${ }^{1} \mathrm{H}$ NMR spectrum of 6 in $\mathrm{C}_{6} \mathrm{D}_{6}(500 \mathrm{MHz}, \mathrm{ppm})$. 
7. $-\mathrm{NH}_{2} \cdot \mathrm{HCl}(90 \%)$

${ }^{1} \mathrm{H}$ NMR (400 MHz, D $\left.2 \mathrm{O}, \mathrm{ppm}\right): \delta 2.56(\mathrm{~s}, 3 \mathrm{H},-M e)$.

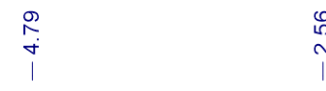

$\mathrm{a}-\mathrm{NH}_{2} \cdot \mathrm{HCl}$

a

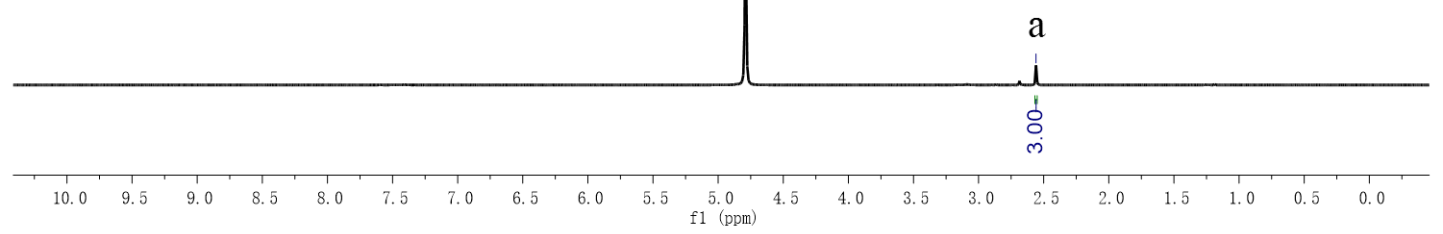

Figure S22. ${ }^{1} \mathrm{H}$ NMR spectrum of 7 in $\mathrm{D}_{2} \mathrm{O}$ (400 MHz, ppm). 
8. $\mathrm{NH}_{2} \cdot \mathrm{HCl}(75 \%)$

${ }^{1} \mathrm{H}$ NMR (400 MHz, D $\left.2 \mathrm{O}, \mathrm{ppm}\right): \delta 2.96\left(\mathrm{t}, J=7.5 \mathrm{~Hz}, 2 \mathrm{H},-\mathrm{CH}_{2}\left(\mathrm{CH}_{2}\right)_{3} \mathrm{CH}_{2} \mathrm{CH}_{3}\right), 1.68$ - $1.55\left(\mathrm{~m}, 2 \mathrm{H},-\mathrm{CH}_{2}\left(\mathrm{CH}_{2}\right)_{3} \mathrm{CH}_{2} \mathrm{CH}_{3}\right), 1.32\left(\mathrm{~d}, J=23.6 \mathrm{~Hz}, 6 \mathrm{H},-\mathrm{CH}_{2}\left(\mathrm{CH}_{2}\right)_{3} \mathrm{CH}_{2} \mathrm{CH}_{3}\right)$, $0.85\left(\mathrm{t}, J=6.5 \mathrm{~Hz}, 3 \mathrm{H},-\mathrm{CH}_{2}\left(\mathrm{CH}_{2}\right)_{3} \mathrm{CH}_{2} \mathrm{CH}_{3}\right)$.

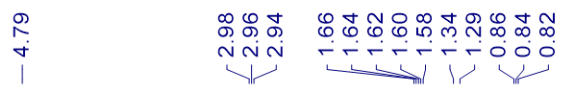

$\overbrace{\mathrm{d}}^{\mathrm{b}} \overbrace{\mathrm{NH}_{2}}^{\mathrm{a}} \cdot \mathrm{HCl}$

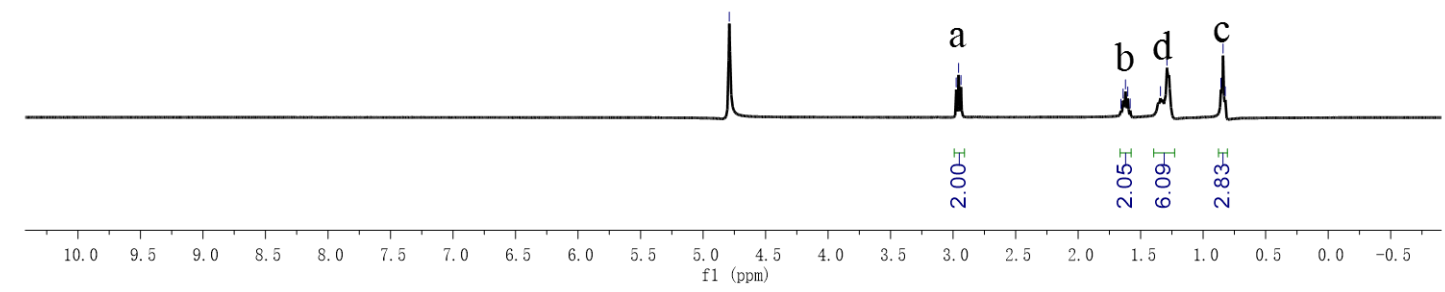

Figure S23. ${ }^{1} \mathrm{H}$ NMR spectrum of 8 in $\mathrm{D}_{2} \mathrm{O}(400 \mathrm{MHz}, \mathrm{ppm})$. 
9.

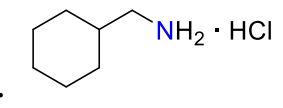

${ }^{1} \mathrm{H}$ NMR (400 MHz, D $\left.2 \mathrm{O}, \mathrm{ppm}\right): \delta 2.82\left(\mathrm{~d}, J=7.0 \mathrm{~Hz}, 2 \mathrm{H},-\mathrm{CH}_{2} \mathrm{C}_{6} \mathrm{H}_{11}\right), 1.70(\mathrm{~d}, J=$ $\left.12.2 \mathrm{~Hz}, 4 \mathrm{H},-\mathrm{CH}_{2} \mathrm{C}_{6} H_{11}\right), 1.63\left(\mathrm{~d}, J=13.5 \mathrm{~Hz}, 2 \mathrm{H},-\mathrm{CH}_{2} \mathrm{C}_{6} H_{11}\right), 1.21(\mathrm{~d}, J=27.5$, $\left.12.4 \mathrm{~Hz}, 4 \mathrm{H},-\mathrm{CH}_{2} \mathrm{C}_{6} H_{11}\right), 0.98\left(\mathrm{t}, J=10.8 \mathrm{~Hz}, 1 \mathrm{H},-\mathrm{CH}_{2} \mathrm{C}_{6} H_{11}\right)$.<smiles>ClCNCC1CCCCC1</smiles>
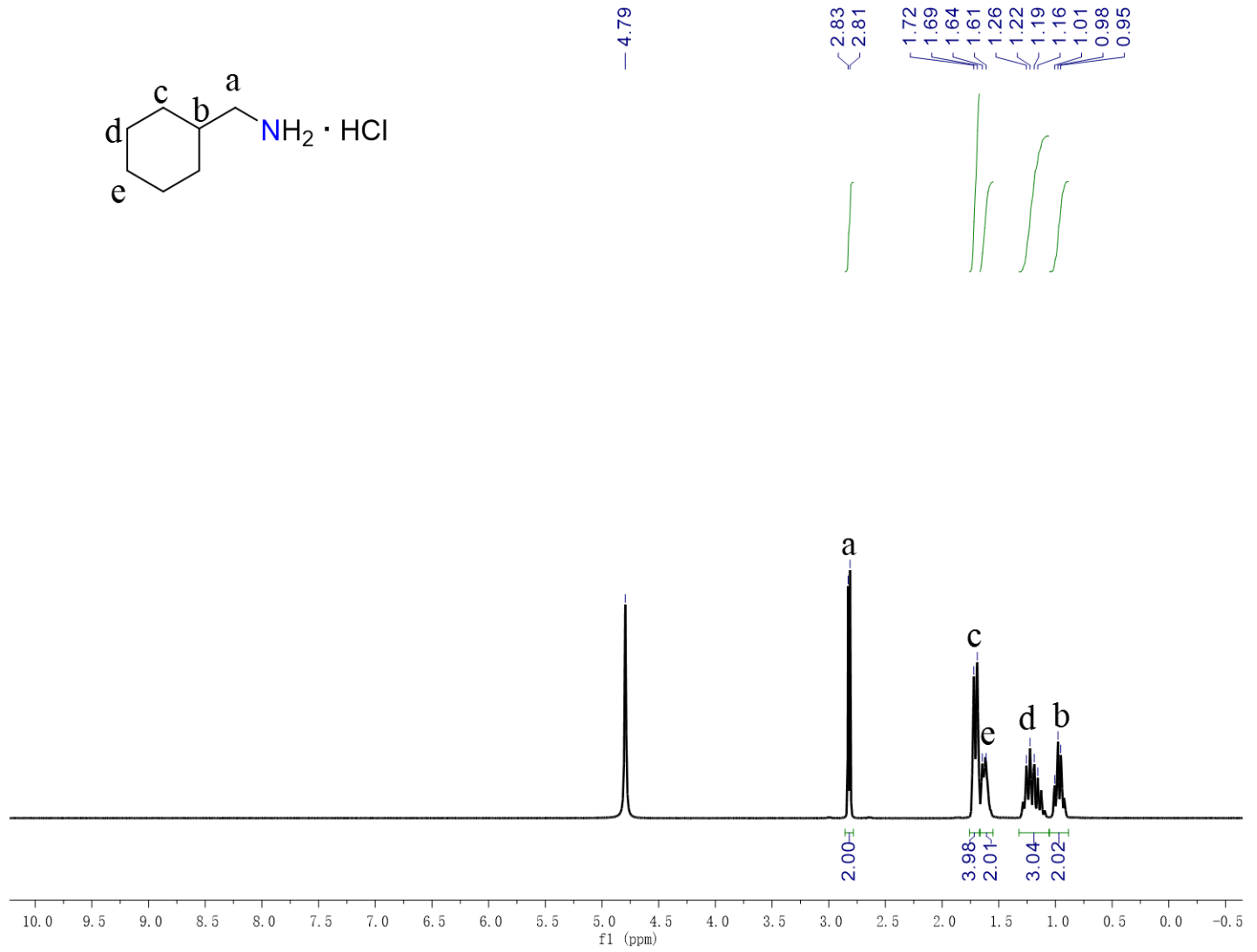

Figure S24. ${ }^{1} \mathrm{H}$ NMR spectrum of 9 in $\mathrm{D}_{2} \mathrm{O}(400 \mathrm{MHz}, \mathrm{ppm})$. 
10. $\overbrace{(91 \%)}^{\mathrm{NH}_{2} \cdot \mathrm{HCl}}$

${ }^{1} \mathrm{H}$ NMR (400 MHz, $\left.\mathrm{D}_{2} \mathrm{O}, \mathrm{ppm}\right): \delta 7.31\left(\mathrm{q}, J=7.9 \mathrm{~Hz}, 4 \mathrm{H},-\mathrm{CH}_{2} P h \mathrm{Me}\right), 4.12(\mathrm{~s}, 2 \mathrm{H}$, $\mathrm{CH}_{2} \mathrm{PhMe}$ ), 2.33 (s, 3H, $\mathrm{CH}_{2} \mathrm{PhMe}$ ).

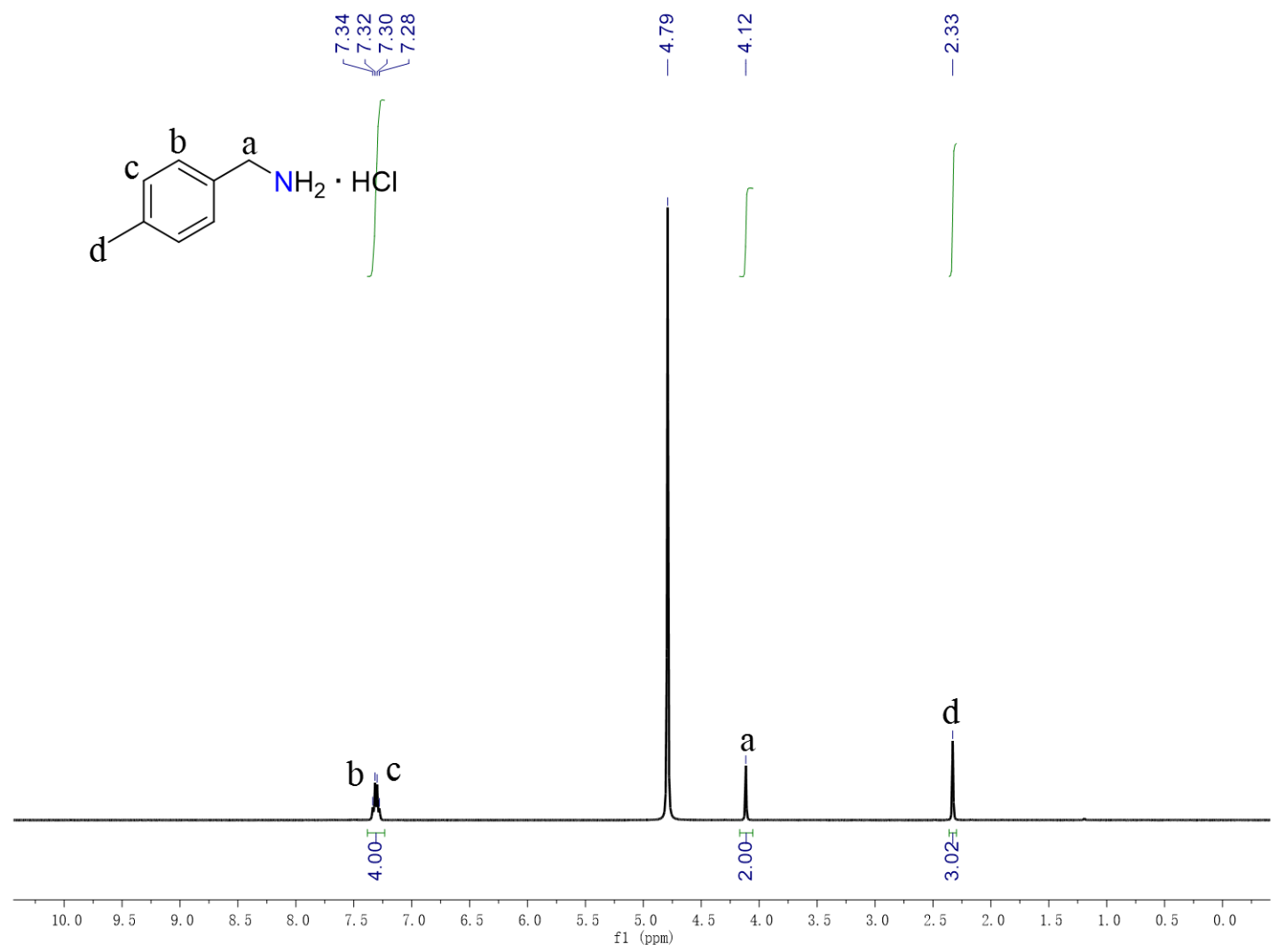

Figure S25. ${ }^{1} \mathrm{H}$ NMR spectrum of $\mathbf{1 0}$ in $\mathrm{D}_{2} \mathrm{O}$ (400 MHz, ppm). 
11. $(68 \%)$

${ }^{1} \mathrm{H}$ NMR (400 MHz, $\left.\mathrm{D}_{2} \mathrm{O}, \mathrm{ppm}\right): \delta 7.36\left(\mathrm{~s}, 2 \mathrm{H},-\mathrm{CH}_{2} P h \mathrm{OMe}\right), 7.01(\mathrm{~s}, 2 \mathrm{H}$, $\left.-\mathrm{CH}_{2} \mathrm{PhOMe}\right), 4.09$ (s, 2H, $\left.-\mathrm{CH}_{2} \mathrm{PhOMe}\right), 3.80$ (s, 3H, - $\left.\mathrm{CH}_{2} \mathrm{PhOMe}\right)$.
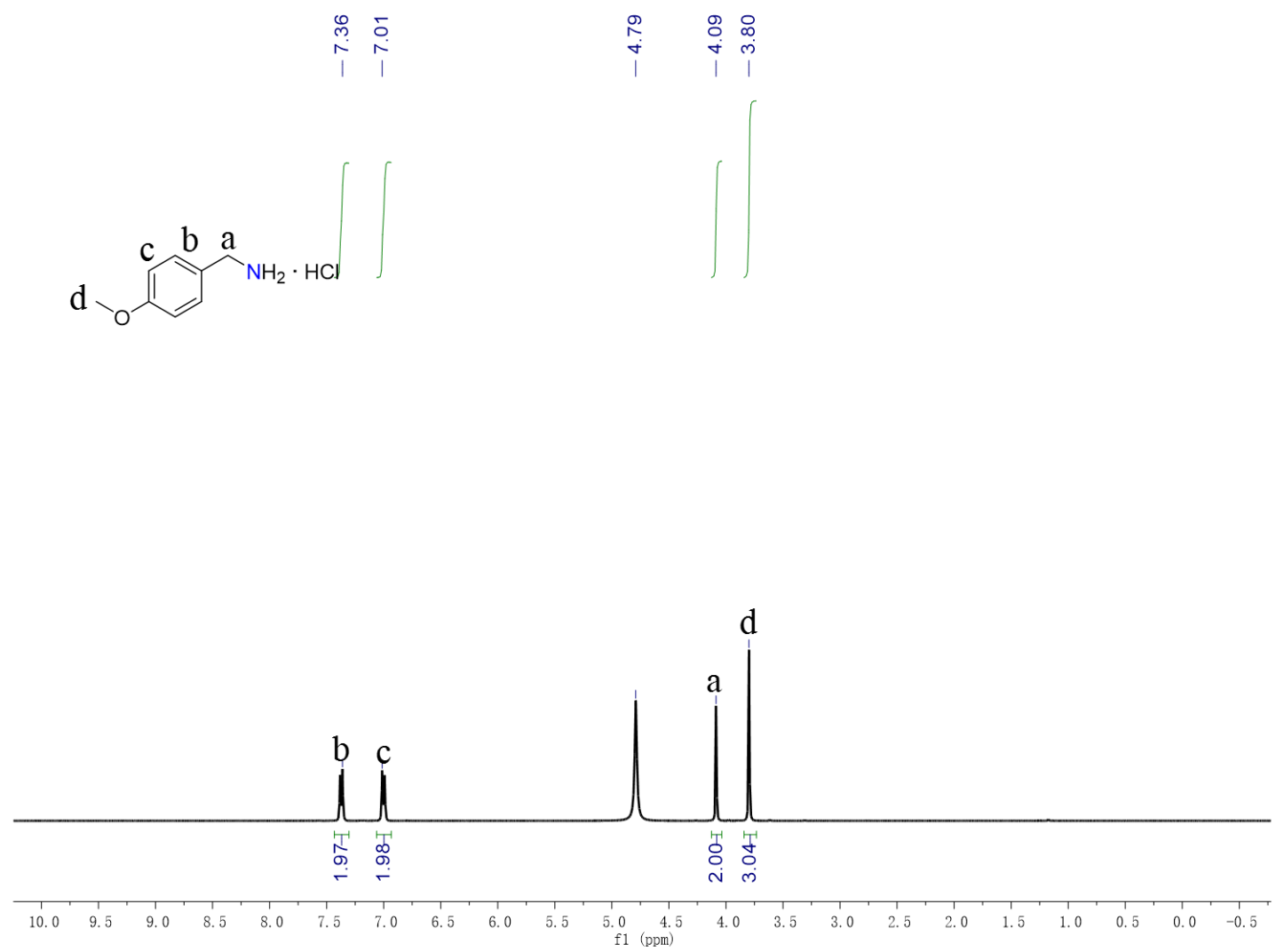

Figure S26. ${ }^{1} \mathrm{H}$ NMR spectrum of $\mathbf{1 1}$ in $\mathrm{D}_{2} \mathrm{O}$ (400 MHz, ppm). 
12.

$\mathrm{NH}_{2} \cdot \mathrm{HCl}(76 \%)$

${ }^{1} \mathrm{H}$ NMR (400 MHz, $\left.\mathrm{D}_{2} \mathrm{O}, \mathrm{ppm}\right): \delta 7.45\left(\mathrm{~s}, 5 \mathrm{H},-\mathrm{CH}_{2} \mathrm{Ph}\right), 4.16\left(\mathrm{~s}, 2 \mathrm{H},-\mathrm{CH}_{2} \mathrm{Ph}\right)$.

b
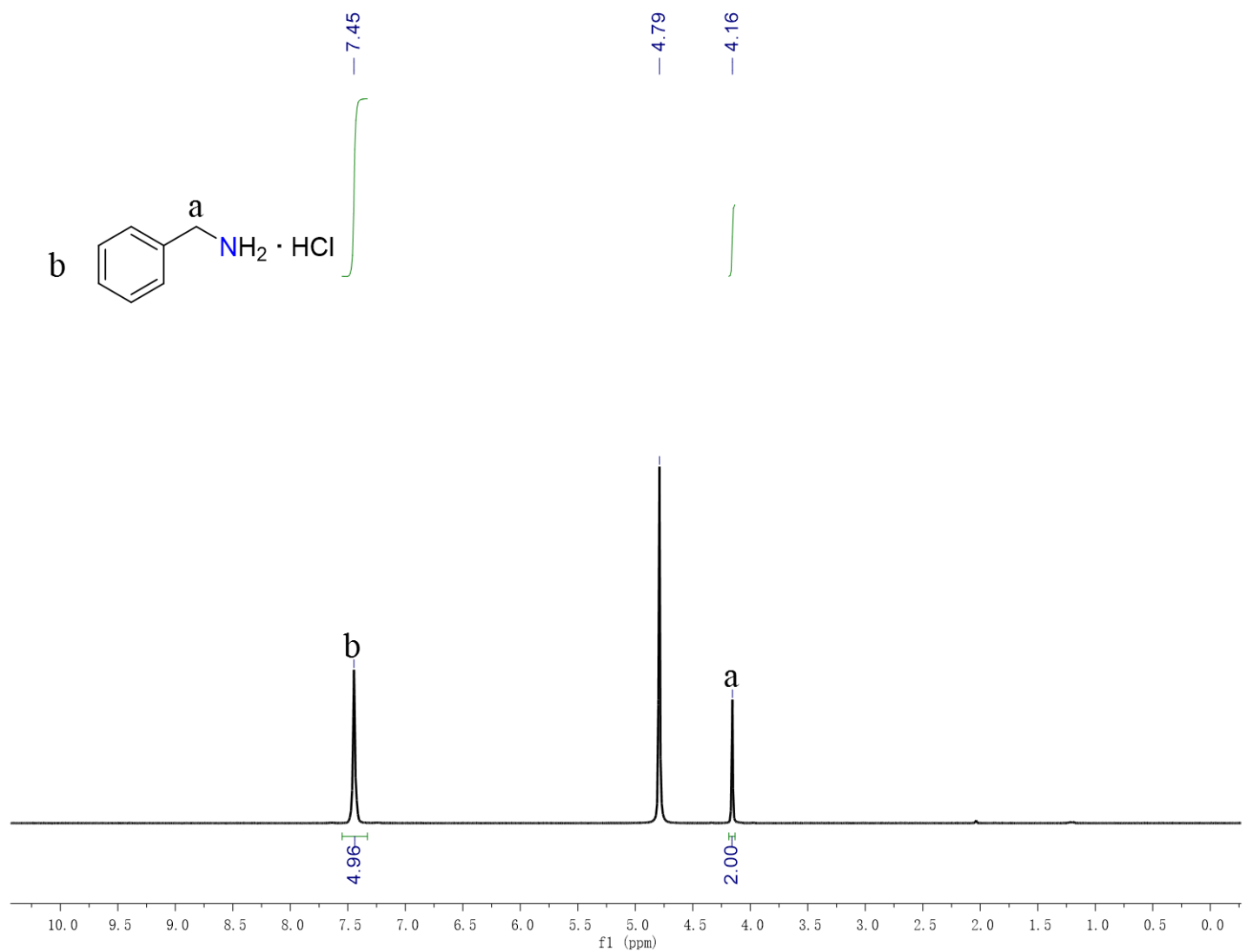

Figure S27. ${ }^{1} \mathrm{H}$ NMR spectrum of 12 in $\mathrm{D}_{2} \mathrm{O}(400 \mathrm{MHz}, \mathrm{ppm})$. 
13.

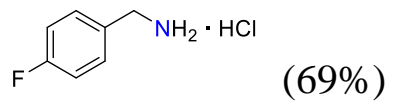

${ }^{1} \mathrm{H}$ NMR (400 MHz, $\left.\mathrm{D}_{2} \mathrm{O}, \mathrm{ppm}\right): \delta 7.44\left(\mathrm{~s}, 2 \mathrm{H},-\mathrm{CH}_{2} P h \mathrm{~F}\right), 7.16(\mathrm{t}, J=8.6 \mathrm{~Hz}, 2 \mathrm{H}$, $\left.-\mathrm{CH}_{2} \mathrm{PhF}\right), 4.14\left(\mathrm{~s}, 2 \mathrm{H},-\mathrm{CH}_{2} \mathrm{PhF}\right)$.

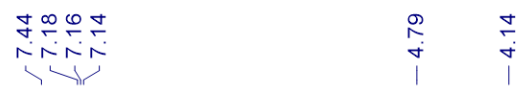<smiles>Fc1ccc(CNCCl)cc1</smiles>

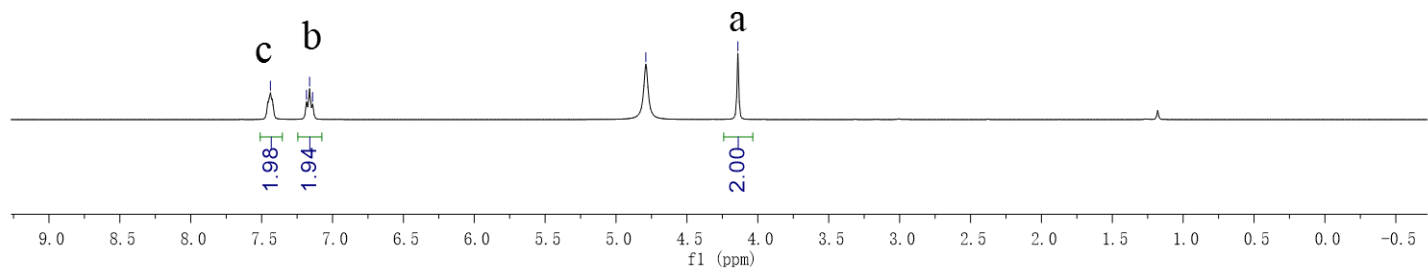

Figure S28. ${ }^{1} \mathrm{H}$ NMR spectrum of $\mathbf{1 3}$ in $\mathrm{D}_{2} \mathrm{O}$ (400 MHz, ppm). 
14. $\mathrm{O}_{2} \mathrm{~N} \mathrm{NH}_{2} \cdot \mathrm{HCl}$

${ }^{1} \mathrm{H}$ NMR (500 MHz, $\left.\mathrm{D}_{2} \mathrm{O}, \mathrm{ppm}\right): \delta 8.32\left(\mathrm{~d}, J=8.1 \mathrm{~Hz}, 2 \mathrm{H},-\mathrm{CH}_{2} P h \mathrm{NO}_{2}\right), 7.69(\mathrm{~d}, J=$ $\left.8.0 \mathrm{~Hz}, 2 \mathrm{H},-\mathrm{CH}_{2} \mathrm{PhNO}_{2}\right), 4.35$ (s, $\left.2 \mathrm{H},-\mathrm{CH}_{2} \mathrm{PhNO}_{2}\right)$.

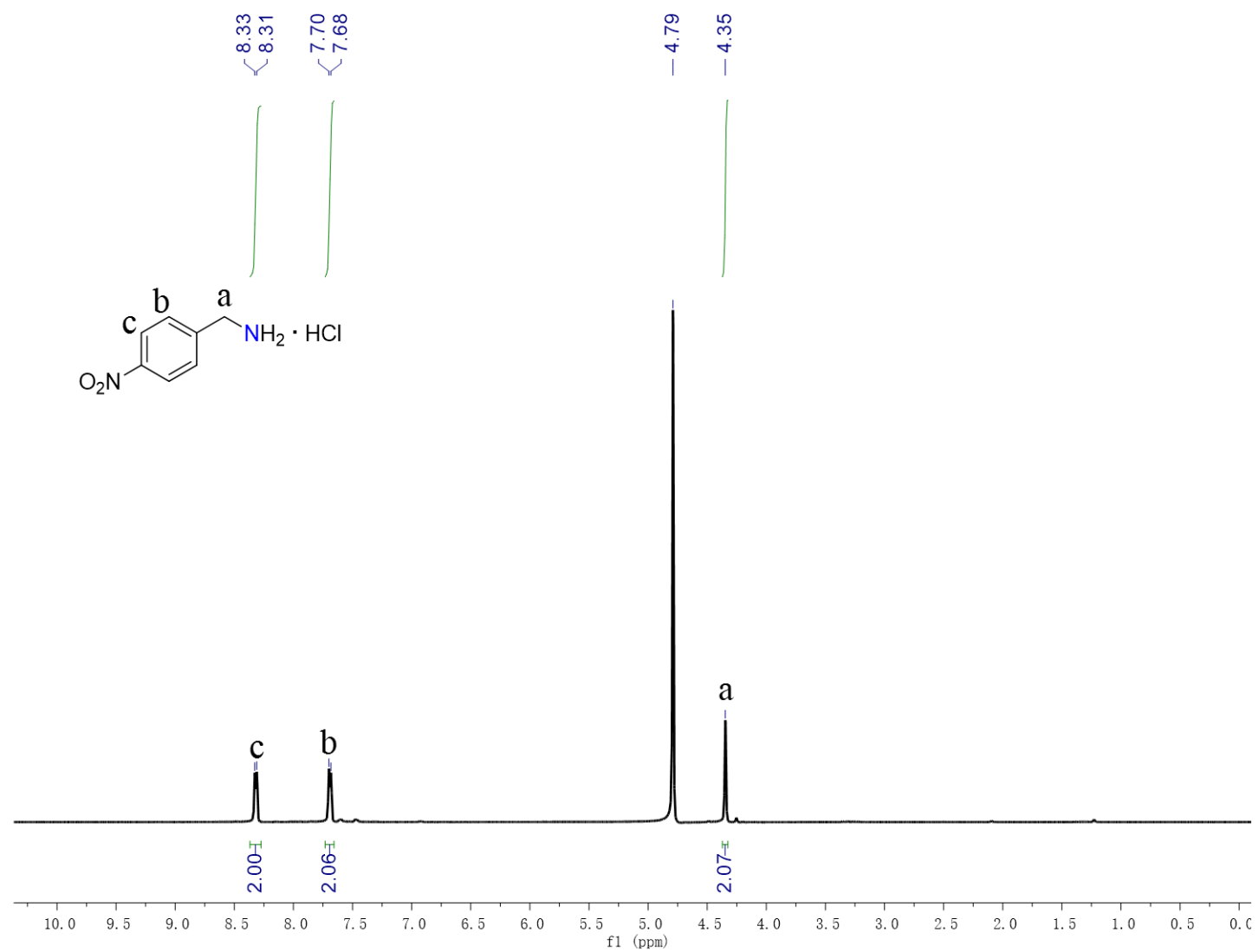

Figure S29. ${ }^{1} \mathrm{H}$ NMR spectrum of 14 in $\mathrm{D}_{2} \mathrm{O}(500 \mathrm{MHz}, \mathrm{ppm})$. 
15.

${ }^{1} \mathrm{H}$ NMR (400 MHz, D $\left.2 \mathrm{O}, \mathrm{ppm}\right): \delta 7.42\left(\mathrm{~d}, J=13.2 \mathrm{~Hz}, 4 \mathrm{H},-\mathrm{CH}_{2} P h \mathrm{Cl}\right), 4.15(\mathrm{~s}, 2 \mathrm{H}$, $\left.-\mathrm{CH}_{2} \mathrm{PhCl}\right)$.
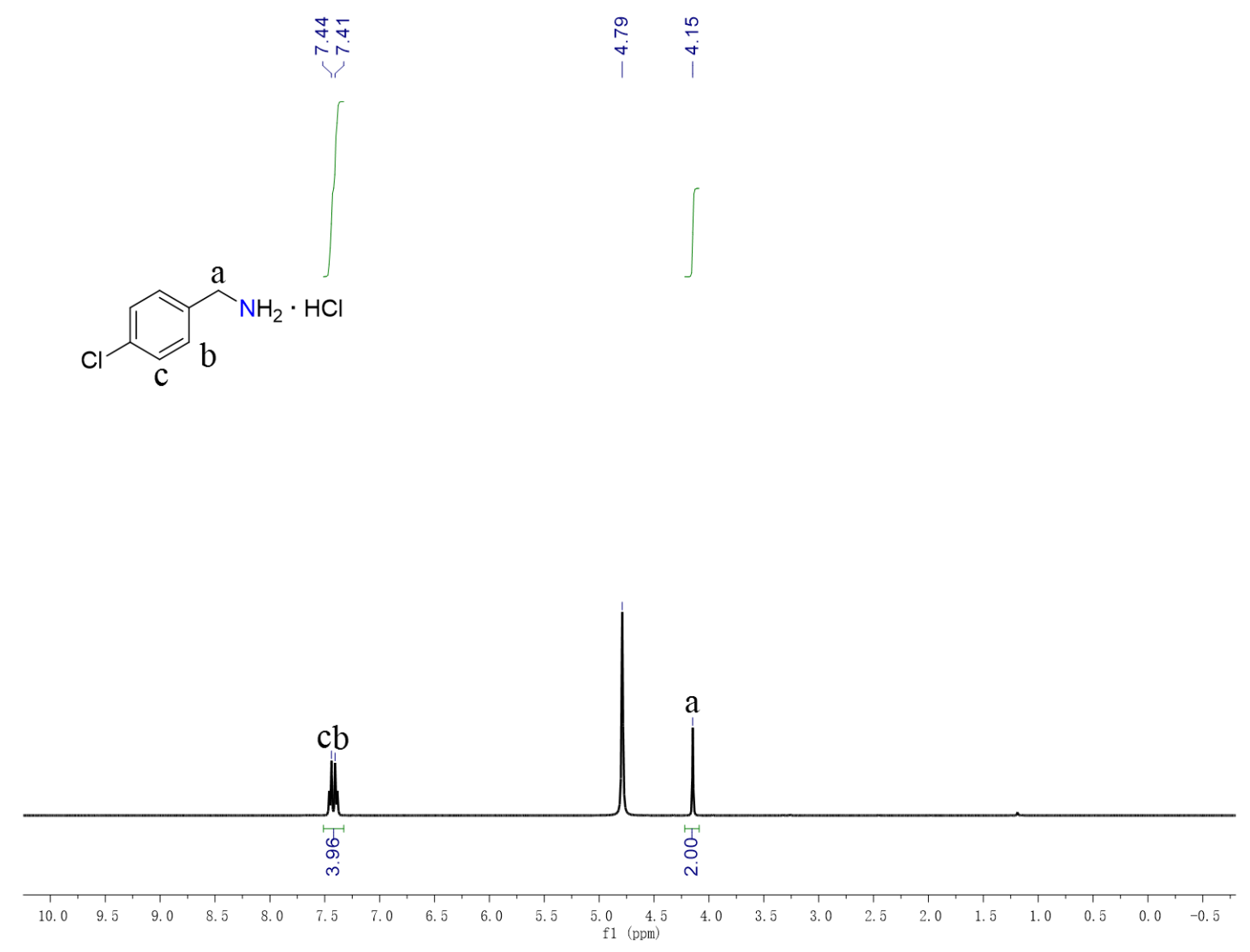

Figure S30. ${ }^{1} \mathrm{H}$ NMR spectrum of 15 in $\mathrm{D}_{2} \mathrm{O}$ (400 MHz, ppm). 
16.

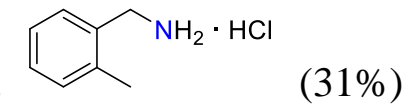

${ }^{1} \mathrm{H}$ NMR (500 MHz, $\mathrm{D}_{2} \mathrm{O}$ ), ppm: $\delta 7.35\left(\mathrm{dd}, J=17.8,9.3 \mathrm{~Hz}, 4 \mathrm{H},-\mathrm{CH}_{2} P h \mathrm{Me}\right), 4.24$ (s, 2H, $\left.-\mathrm{CH}_{2} \mathrm{PhMe}\right), 2.40\left(\mathrm{~s}, 3 \mathrm{H},-\mathrm{CH}_{2} \mathrm{PhMe}\right)$.
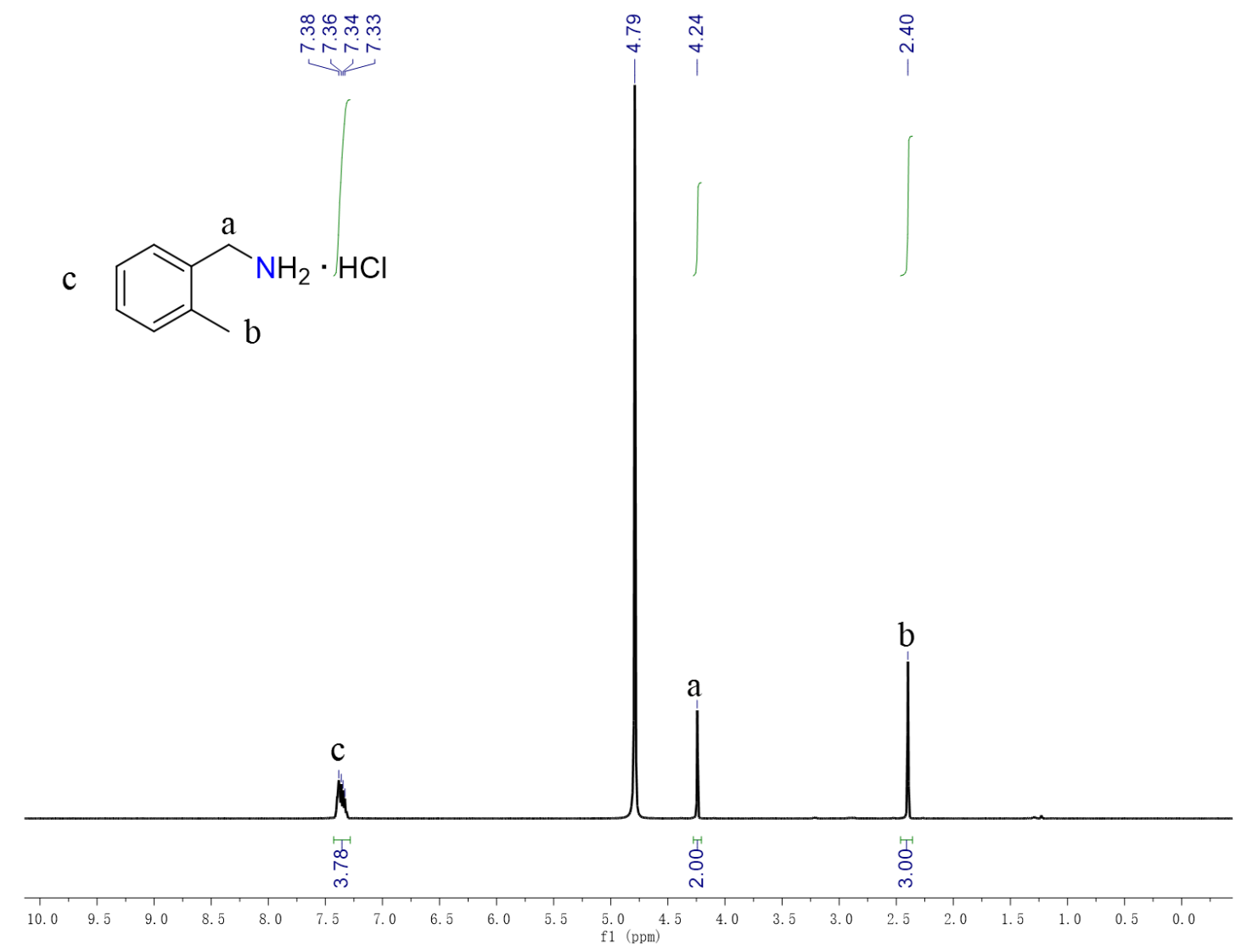

Figure S31. ${ }^{1} \mathrm{H}$ NMR spectrum of $\mathbf{1 6}$ in $\mathrm{D}_{2} \mathrm{O}(500 \mathrm{MHz}, \mathrm{ppm})$. 
17.

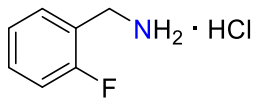

$(64 \%)$

${ }^{1} \mathrm{H}$ NMR (500 MHz, $\left.\mathrm{D}_{2} \mathrm{O}, \mathrm{ppm}\right): \delta 7.49\left(\mathrm{~s}, 2 \mathrm{H},-\mathrm{CH}_{2} P h \mathrm{~F}\right), 7.28(\mathrm{~d}, J=16.5,8.4 \mathrm{~Hz}$, $\left.\left.2 \mathrm{H},-\mathrm{CH}_{2} \mathrm{PhF}\right)\right), 4.27\left(\mathrm{~s}, 2 \mathrm{H},-\mathrm{CH}_{2} \mathrm{PhF}\right)$
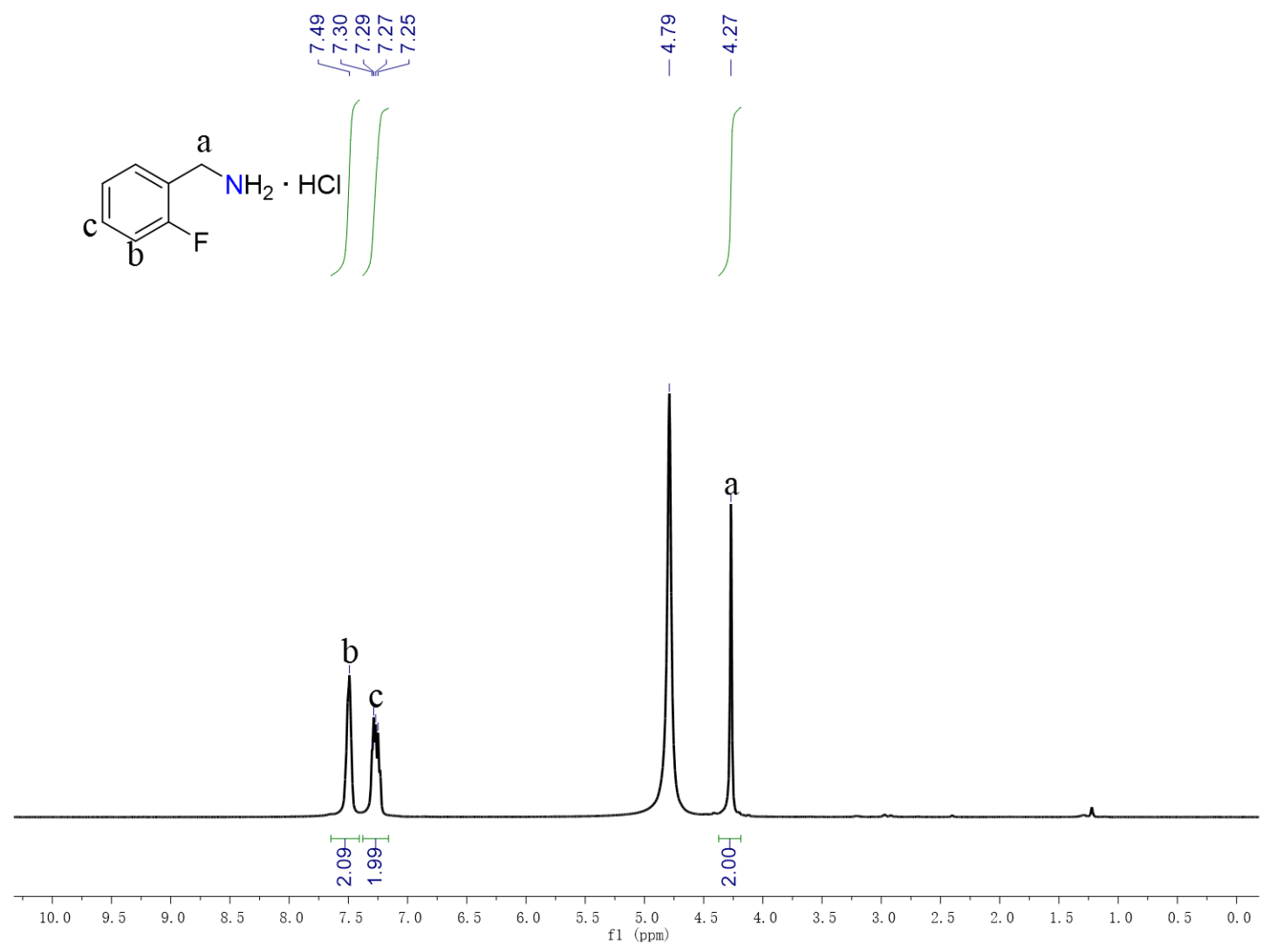

Figure S32. ${ }^{1} \mathrm{H}$ NMR spectrum of $\mathbf{1 7}$ in $\mathrm{D}_{2} \mathrm{O}(500 \mathrm{MHz}, \mathrm{ppm})$. 
18.

(II $\mathrm{NH}_{2} \cdot \mathrm{HCl}(52 \%)$

${ }^{1} \mathrm{H}$ NMR (400 MHz, D $\left.2 \mathrm{O}, \mathrm{ppm}\right): \delta 7.49\left(\mathrm{~s}, 1 \mathrm{H},-\mathrm{CH}_{2} \mathrm{C}_{4} \mathrm{SH}_{3}\right), 7.23\left(\mathrm{~s}, 1 \mathrm{H},-\mathrm{CH}_{2} \mathrm{C}_{4} \mathrm{SH}_{3}\right)$, $7.09\left(\mathrm{~s}, 1 \mathrm{H},-\mathrm{CH}_{2} \mathrm{C}_{4} \mathrm{SH}_{3}\right), 4.39\left(\mathrm{~s}, 2 \mathrm{H},-\mathrm{CH}_{2} \mathrm{C}_{4} \mathrm{SH}_{3}\right)$.

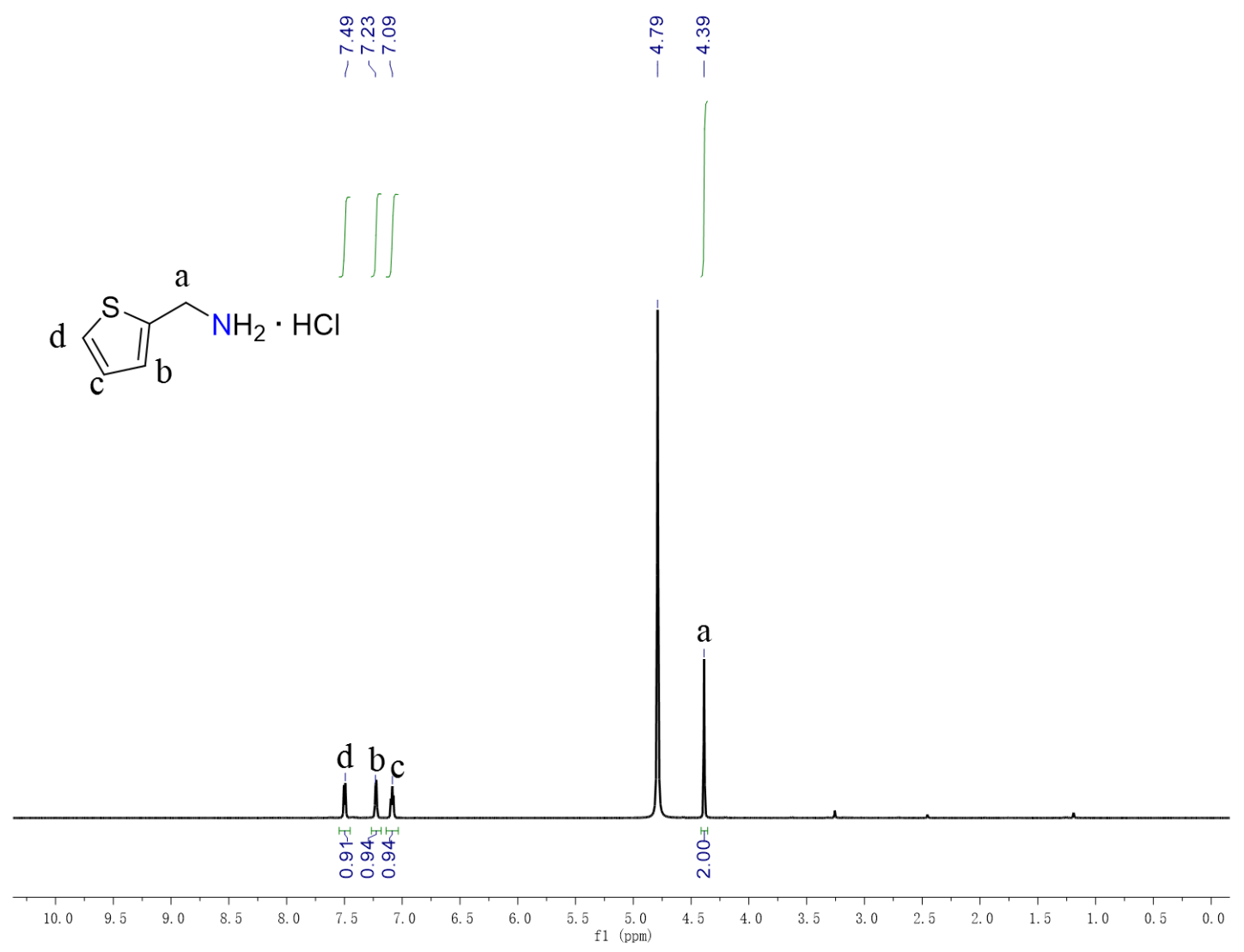

Figure S33. ${ }^{1} \mathrm{H}$ NMR spectrum of $\mathbf{1 8}$ in $\mathrm{D}_{2} \mathrm{O}(400 \mathrm{MHz}, \mathrm{ppm})$. 


\section{Reference}

(1) Y. Sarazin, R. H. Howard, D. L. Hughes, S. M. Humphrey, M. Bochmann, Dalton Trans. 2006, 2, 340-350.

(2) P. Ye, Y. Shao, X. Ye, F. Zhang, R. Li, J. Sun, B. Xu, J. Chen, Org. Lett. 2020, 22, $1306-1310$. 